\title{
VOC species and emission inventory from vehicles and their SOA formation potentials estimation in Shanghai, China
}

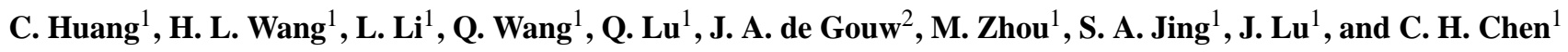 \\ ${ }^{1}$ State Environmental Protection Key Laboratory of the Formation and Prevention of Urban Air Pollution Complex, Shanghai \\ Academy of Environmental Sciences, Shanghai, China \\ ${ }^{2}$ Earth System Research Laboratory, Chemical Sciences Division, NOAA, 325 Broadway, Boulder, Colorado 80305, USA
}

Correspondence to: C. Huang (huangc@ saes.sh.cn)

Received: 22 December 2014 - Published in Atmos. Chem. Phys. Discuss.: 17 March 2015

Revised: 14 September 2015 - Accepted: 16 September 2015 - Published: 6 October 2015

\begin{abstract}
Volatile organic compound (VOC) species from vehicle exhausts and gas evaporation were investigated by chassis dynamometer and on-road measurements of nine gasoline vehicles, seven diesel vehicles, five motorcycles, and four gas evaporation samples. The secondary organic aerosol (SOA) mass yields of gasoline, diesel, motorcycle exhausts, and gas evaporation were estimated based on the mixing ratio of measured $\mathrm{C} 2-\mathrm{C} 12$ VOC species and inferred carbon number distributions. High aromatic contents were measured in gasoline exhausts and contributed comparatively more SOA yield. A vehicular emission inventory was compiled based on a local survey of on-road traffic in Shanghai and real-world measurements of vehicle emission factors from previous studies in the cities of China. The inventorybased vehicular organic aerosol (OA) productions to total $\mathrm{CO}$ emissions were compared with the observed $\mathrm{OA}$ to $\mathrm{CO}$ concentrations $(\triangle \mathrm{OA} / \triangle \mathrm{CO})$ in the urban atmosphere. The results indicate that vehicles dominate the primary organic aerosol (POA) emissions and OA production, which contributed about 40 and $60 \%$ of OA mass in the urban atmosphere of Shanghai. Diesel vehicles, which accounted for less than $20 \%$ of vehicle kilometers of travel (VKT), contribute more than $90 \%$ of vehicular POA emissions and $80-90 \%$ of OA mass derived by vehicles in urban Shanghai. Gasoline exhaust could be an important source of SOA formation. Tightening the limit of aromatic content in gasoline fuel will be helpful to reduce its SOA contribution. Intermediate-volatile organic compounds (IVOCs) in vehicle exhausts greatly contribute to SOA formation in the urban atmosphere of China. However, more experiments need to be conducted to determine the contributions of IVOCs to OA pollution in China.
\end{abstract}

\section{Introduction}

Secondary organic aerosol (SOA) accounts for a significant fraction of ambient tropospheric aerosol (Hallquist et al., 2009; Jimenez et al., 2009). De Gouw and Jimenez (2009) suggested that SOA from urban sources may be the dominant source of organic aerosol globally between 30 and $50^{\circ}$ latitude.

Gas-phase oxidation of volatile organic compounds (VOCs) has traditionally been considered to be the major source of urban SOA formation. VOCs are oxidized to low vapor pressure reaction products by $\mathrm{OH}$ radicals, ozone, and $\mathrm{NO}_{3}$ radicals, and eventually form $\mathrm{OA}$ in the atmosphere. Odum et al. (1997) investigated the SOA formation from vaporized reformulated gasoline and found that single light aromatic hydrocarbons are responsible for the majority of SOA formation. Kleindienst et al. (2002) verified that $75-85 \%$ of the SOA was due to reaction products of C6-C9 light aromatic compounds from automobile exhausts. Robinson et al. (2007) further recognized that IVOCs and semi-volatile organic compounds (SVOCs) are also important sources for OA production based on the smog-chamber studies of diesel exhaust and wood fires (Weitkamp et al., 2007; Grieshop et al., 2009). Their subsequent study pointed out that IVOCs, such as long-chain and branched alkanes from vehicle exhausts, play a more important role in SOA production compared to other combustion emissions (Jathar et al., 2013). A recent study from Zhao et al. (2014) concluded that primary IVOCs were estimated to produce about $30 \%$ of newly formed SOA in the afternoon during the CalNex campaign in Pasadena, California. 
Due to the abundance of reactive organic compounds, vehicle emissions have been recognized as a major source of urban SOA formation (Stone et al., 2009; Liu et al., 2012; Borbon et al., 2013). Laboratory chamber studies also report significant SOA production from diesel, gasoline, and motorcycle exhaust photo-oxidation (Hung and Wang, 2006; Weitkamp et al., 2007; Chirico et al., 2010; Nordin et al., 2013; Platt et al., 2013). Current research is now focusing on the relative importance of gasoline and diesel vehicles to urban SOA formation. Bahreini et al. (2012) and Hayes et al. (2013) suggested gasoline emissions dominate over diesel in urban SOA formation by field studies. Gentner et al. (2012) argued that diesel is responsible for 65 to $90 \%$ of vehicular-derived SOA based on the estimation of SOA formation from gasoline and diesel fuel compositions.

Shanghai is one of the most urbanized cities in the Yangtze River Delta (YRD) region in China. The YRD region occupies $2 \%$ of land area and generates $8-12 \%$ of the primary $\mathrm{PM}_{2.5}$ and the emissions of its precursors in China (Huang et al., 2011). Motor vehicles are the fastest growing source of pollution in the megacities of China. The number of vehicles in Shanghai has doubled in the last decade and reached 2.6 million (about 107 units per 1000 capita) in 2012 (SCCTPI, 2012). Gasoline and diesel vehicles increased by 2.8 and 1.3 times, respectively, while motorcycles decreased by $36 \%$. Vehicular emissions have been recognized as the largest source of VOCs in urban Shanghai, which contributes $25-28 \%$ of the measured VOC concentrations. Other VOC emission sources were solvent usage, chemical industry, petrochemical industry, and coal burning, etc. (Cai et al., 2010; Wang et al., 2013). Yuan et al. (2013) indicated that VOC emissions are large contributors to SOA formation through field measurements at a receptor site in eastern China. Huang et al. (2012) and Huang, X. F. et al. (2013) reported that $28.7-32.1 \%$ of the fine particle mass is organic matter (OM) and $30.2-76 \%$ of OM is contributed by SOA in the atmosphere of Shanghai and its surrounding areas. Based on the historical measurement data of organic (OC) and element carbon (EC) in $\mathrm{PM}_{2.5}$ in the atmosphere in urban Shanghai, the OC / EC ratio showed a growing trend from 1999 to 2011, which implies that the secondary fraction of organic matter is playing an increasing role in urban Shanghai (Ye et al., 2003; Feng et al., 2005; Hou et al., 2011; Cao et al., 2013; Feng et al., 2013). However, the contribution of VOC emissions to SOA formation and the relative importance of vehicular emissions remains unclear. At present, vehicle use is experiencing a rapid growth episode in the cities of China. Understanding the contribution of vehicular VOC emissions to SOA formation will be helpful to identify the source of OA and $\mathrm{PM}_{2.5}$ pollution in China.

In this study, we first constructed a vehicular emission inventory of Shanghai for the year of 2012. Then the SOA yields of VOCs emissions from different vehicle types were discussed based on the new measurements of VOCs species from a fleet of vehicles in Shanghai. Finally, we calculated the inventory-based vehicular OA production with the ambient observation data to evaluate the OA contribution of vehicle emissions. The main purpose of this study is to discuss: (1) the contribution of vehicle emissions to OA in urban Shanghai; (2) the relative contributions of gasoline and diesel vehicles to vehicle-derived OA.

\section{Materials and methods}

\subsection{Vehicular emission inventory establishment}

\subsubsection{Methodology of emission inventory compilation}

We developed emission inventories for the pollutants including VOCs, CO, EC, and OC with the IVE (International Vehicle Emissions) model for Shanghai, China. The methodology of the model has been introduced by Wang et al. (2008). VKT, vehicle flow distribution, driving pattern, fleet composition and the emission factor of each vehicle type were five key parameters for the development of the vehicle emission inventory. Vehicle emissions can be calculated with Eq. (1):

$E=\sum_{t}\left\{\mathrm{VKT} \cdot f_{[t]} \cdot \mathrm{EF}_{[t]} \cdot \sum_{d}\left[f_{[\mathrm{d} t]} \cdot K_{[\mathrm{d} t]}\right]\right\}$,

where $E$ is the emission amount of each vehicle type $(g)$; VKT is vehicle kilometers of travel of each vehicle type $(\mathrm{km}) ; f_{[t]}$ is the fleet composition of the specific technology of each vehicle type (\%), such as fuel type, engine size, and emission standards. $\mathrm{EF}_{[t]}$ is the emission factor of each vehicle technology $\left(\mathrm{g} \mathrm{km}^{-1}\right) ; f_{[\mathrm{d} t]}$ is the fraction of the driving pattern (\%); $K_{[\mathrm{d} t]}$ is the correction factor of each driving pattern determined by the model (unitless). Evaporative emissions are also calculated with Eq. (1). $\mathrm{EF}_{[t]}$ will be the evaporative emission factor of each vehicle technology as the evaporative emissions are calculated.

\subsubsection{Road traffic data survey}

VKTs and their weights on three road types (including highway, arterial road, and residential road) were surveyed from transportation for the year of 2012. VKTs on each road type were further separated into seven vehicle types by the use of video camera surveys. The distributions of each vehicle type were surveyed on various road types with video cameras from March to May. About 4000 valid hours were obtained on 15 roads covering three road types. Survey days included weekdays and weekends, and each day covered $24 \mathrm{~h}$. The results show that light-duty vehicles (including light-duty cars, light-duty trucks, and taxis) are the major vehicle types on the road, accounting for $56 \%$ of the total flows. Heavy-duty vehicles (including heavy-duty buses, heavy-duty trucks, and city buses) comprise $19 \%$ of the whole VKTs in Shanghai. GPS data were used to determine the driving patterns of various vehicle types. The driving patterns were determined by the average speeds and VSP (vehicle-specific power) distributions. We installed GPS units on light-duty cars, taxis, 
buses, and heavy-duty trucks to record the driving speeds and altitudes second by second. About $150 \mathrm{~h}$ of valid GPS data were collected in this study. The data covered $2831 \mathrm{~km}$ of roads and were composed of three road types and four vehicle types. VSP of each vehicle and road type can be calculated with Eq. (2) introduced by Jimenez (1999).

$$
\begin{aligned}
& \operatorname{VSP}\left(\mathrm{kW} \cdot t^{-1}\right)=v \cdot[1.1 a+9.81 \cdot(a \cdot \tan (\sin (\operatorname{grade}))) \\
& +0.132]+0.000302 \cdot v^{3}
\end{aligned}
$$

where $v$ is vehicle speed $\left(\mathrm{m} \mathrm{s}^{-1}\right) ; a$ is vehicle acceleration $\left(\mathrm{m} \mathrm{s}^{-2}\right)$; grade is vertical rise/slope length. Table 1 shows the daily VKT and average speeds of various vehicle and road types in 2012 .

\subsubsection{Fleet composition data survey}

Fleet composition data were used to separate the VKT of each vehicle type (as shown in Table 1) into the fractions of specific technologies, such as fuel type, engine size, and emission standards. The data were determined by the ratios of the populations of specific technologies in the vehicle information database from the Vehicle Management Department of Public Security Bureau of Shanghai. We call this the "static" fleet. Light-duty cars and taxis were mainly composed of gasoline vehicles, which occupied 98 and $97 \%$, respectively. Diesel vehicles dominated in light-duty trucks, heavy-duty buses, heavy-duty trucks, and city buses, comprising 56, 91, 89, and $98 \%$, respectively. Euro 2 (emission regulation) vehicles were the majority of light-duty cars and light-duty trucks, accounting for 51 and $68 \%$, respectively. Heavy-duty buses and trucks were mainly composed of Euro 2 and Euro 3 diesel vehicles, which comprised 40 and $45 \%$ of each vehicle type. However, the fraction of each specific technology should be changed according to its occurrence frequency in the real-world. Generally, older vehicles show less occurrence frequency than newer vehicles, which means the annual mileage of an older vehicle should be less than the newer one. For this reason, we considered adjusting the fleet compositions according to their real-world annual average mileage. About 30000 vehicles were surveyed at four inspection stations in this study. Vehicle age and odometer reading were recorded for each vehicle. The survey data showed that the annual average mileage of light-duty trucks, heavy-duty buses, and heavy-duty trucks tended to decrease with the increase of their vehicle ages. The adjusted fleet compositions were determined by the multiplication of vehicle populations and their surveyed annual mileage. Figure 1 shows the static and adjusted fraction by each vehicle type in Shanghai. It is indicated that the adjusted fractions of the older vehicles with pre-Euro and Euro 1 emission standards for light-duty trucks, heavy-duty buses, heavy-duty trucks, and city buses were much lower than those of the static ones. Correspondingly, the adjusted fractions of the newer vehicles with Euro
3 emission standards increased a lot compared with the static ones.

\subsubsection{Vehicle emission factors}

The emission factors of each type of vehicle technology were modeled with the IVE model. However, most of the default emission factors in the model are based on measurements made in the US. To localize the emission factors in this study, we collected the published emission factors based on the real-world measurements in the previous studies to adjust the modeled emission factors. The measurements were all conducted with portable emission measurement systems (PEMS) under designated driving routes in the cities of China. The cities included Shanghai, Beijing, Guangzhou, Xi' an, Shenzhen, Jinan, and Yichang (Chen et al., 2007; Huo et al., 2012a, b; Wu et al., 2012; Huang, C. et al., 2013). Figure 2 shows the comparisons of the adjusted emission factors with the measured ones. The evaporative emission factors were not adjusted due to the lack of measurement data. Default factors in the model were used to calculate evaporative emissions in this study. It is indicated that the adjusted emission factors of each vehicle type generally fit well with the measured results. The emission factors are reliable to be used to establish the emission inventory.

\subsection{VOC species measurements and SOA yield estimation}

\subsubsection{VOC sampling}

The exhausts from four light-duty gasoline vehicles (LDGVs), five taxis, five heavy-duty diesel trucks (HDDTs), two city buses (buses), and five motorcycles (MTs) were measured in June 2010. LDGVs, taxis, and MTs were fueled by gasoline. HDDTs and buses were fueled by diesel. The emission standards of the tested vehicles covered Euro 1 to Euro 3 and their model years covered 2001 to 2009. All MTs were 4-stroke with $125 \mathrm{cc}$ displacement and without a catalytic converter or any other pollution control device. All gasoline vehicles were equipped with catalytic converters. Diesel vehicles did not install any after-treatment devices like DPFs (diesel particulate filters). Table 2 lists the detailed information of the tested vehicles. Commercially available fuels were used in the test. The fuel quality met the requirements of the local standards in Shanghai. The sulfur contents of both gasoline and diesel fuel were below $50 \mathrm{ppm}$.

All the automobiles were measured on chassis dynamometers. LDGVs and taxis were measured utilizing a vehicle mass analysis system (VMAS), which was widely used in in-use vehicle inspection stations in China. A VOC sample was collected from a one-bag test of the Economic Commission of Europe (ECE) urban cycle. The highest speed reaches $50 \mathrm{~km} \mathrm{~h}^{-1}$ and the average speed is about $18.8 \mathrm{~km} \mathrm{~h}^{-1}$. HDDTs and buses were measured on a loaded-mode test cycle. 
Table 1. Daily VKT and average speeds of various vehicle and road types in Shanghai in 2012.

\begin{tabular}{lrrrrrrrrr}
\hline & \multicolumn{7}{c}{ Daily vehicle kilometers traveled (million km) } & & \\
\cline { 2 - 8 } Road types & $\begin{array}{r}\text { Light-duty } \\
\text { car }\end{array}$ & $\begin{array}{r}\text { Light-duty } \\
\text { truck }\end{array}$ & Taxi & $\begin{array}{r}\text { Heavy-duty } \\
\text { bus }\end{array}$ & $\begin{array}{r}\text { Heavy-duty } \\
\text { truck }\end{array}$ & $\begin{array}{r}\text { City } \\
\text { bus }\end{array}$ & $\begin{array}{r}\text { Motor- } \\
\text { cycle }\end{array}$ & $\begin{array}{r}\text { Total } \\
\text { Average } \\
\text { speed (km h-1) }\end{array}$ \\
\hline Highway & 38.3 & 0.62 & 3.96 & 3.10 & 11.82 & 0.23 & 0.00 & 58.04 & 57.9 \\
Arterial road & 22.6 & 2.93 & 6.16 & 1.12 & 4.73 & 1.58 & 5.29 & 44.41 & 38.64 \\
Residential road & 18.3 & 3.11 & 8.92 & 0.89 & 1.90 & 1.38 & 4.15 & 38.0 \\
Total & 79.2 & 6.66 & 19.04 & 5.11 & 18.45 & 3.19 & 9.44 & 141.09 & 43.0 \\
\hline
\end{tabular}
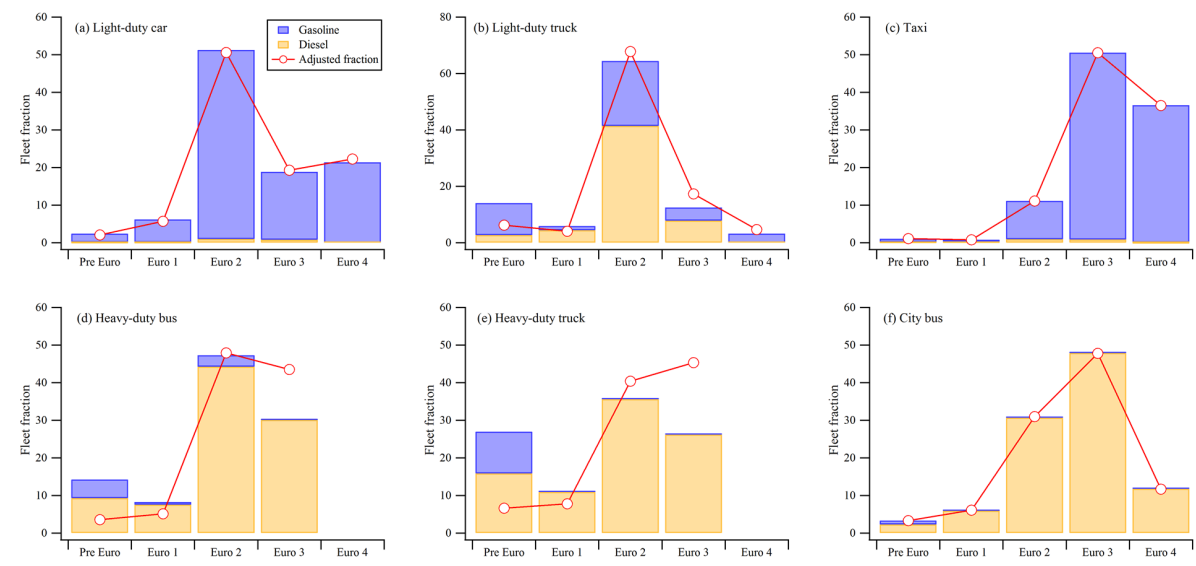

Figure 1. Static and adjusted fractions of each vehicle type in Shanghai.

The tested vehicles were operated on idling and a test cycle which simulates high engine loads under 100, 90, and $80 \%$ of their maximum powers. The highest speed reaches $70 \mathrm{~km} \mathrm{~h}^{-1}$. MT exhausts were sampled while operating on the road. A GPS unit was installed on the tested motorcycles to record the speeds second by second. The highest speed reached $50 \mathrm{~km} \mathrm{~h}^{-1}$ and the average speed was about $20 \mathrm{~km} \mathrm{~h}^{-1}$. Vehicle exhausts were sampled into a Summa canister (Entech Inst., USA) during the whole driving cycle. We also collected the samples of gasoline vapor at four gas stations in Shanghai to analyze the VOC species of nontailpipe gasoline.

\subsubsection{VOC analysis}

Concentration of C2-C12 VOCs in samples were determined by a GC-MS (gas chromatography-mass spectrometer) system (Agilent 7890A/5975C) with standard gases prepared by Spectra Gas. The samples collected in the Summa canister were pre-concentrated to an acceptable level for the analytical devices using a 7100A pre-concentrator (Entech Inst., USA) with an Entech 7016CA automatic sample injector. A $50 \mathrm{~mL}$ sample was extracted by the pre-concentrator into a $1 / 4$ inch liquid nitrogen cold trap to remove water and $\mathrm{CO}_{2}$, and then separated by GC and detected by MS. The carrier gas was helium.

\subsubsection{SOA yield estimation}

To investigate the SOA formation potentials of VOC emissions in vehicle exhausts and gas evaporation, we calculated the SOA yields of the exhausts from gasoline, diesel, and motorcycle vehicles and evaporative emissions with the following equation:

$Y_{j}=\frac{\sum\left(C_{i, j} \times Y_{i}\right)}{\sum \mathrm{VOC}_{j}}$,

where $Y_{j}$ is the SOA yield of source $j$ (unitless); $C_{i, j}$ is the weight percent (by carbon) of species $i$ which can be identified by measurements or references from source $j$ (wt C \%); $\mathrm{VOC}_{j}$ is the weight percent (by carbon) of total identified SOA precursors and unidentified species. Identified nonSOA precursors were excluded from total VOC emissions. The weight percentages of identified species were determined by the measurements above. The unidentified species accounted for about 25, 60, and 50\% in gasoline, diesel, and motorcycle exhausts, respectively. Considering IVOCs which had high SOA formation potentials were not measured in this study, we estimated the amounts of IVOCs including alkanes and aromatics larger than $\mathrm{C} 12$ and polycyclic aromatics based on Gentner et al. (2012) and varied them by 1 order of magnitude. $Y_{i}$ is the yield of species $i$ under high $\mathrm{NO}_{x}$ conditions considering the study was focusing 
Table 2. Test vehicle specifications.

\begin{tabular}{lrrrrr}
\hline ID & Vehicle type & Fuel type & $\begin{array}{r}\text { Emission } \\
\text { standard }\end{array}$ & $\begin{array}{r}\text { Model year } \\
\text { reading }(\mathrm{km})\end{array}$ & Odometer \\
\hline LDGV-1 & Light-duty car & Gasoline & Euro 1 & 2002 & 245306 \\
LDGV-2 & Light-duty car & Gasoline & Euro 2 & 2005 & 59790 \\
LDGV-3 & Light-duty car & Gasoline & Euro 3 & 2008 & 87662 \\
LDGV-4 & Light-duty car & Gasoline & Euro 3 & 2008 & 80856 \\
Taxi-1 & Light-duty taxi & Gasoline & Euro 1 & 2001 & 270000 \\
Taxi-2 & Light-duty taxi & Gasoline & Euro 1 & 2002 & $\sim 100000$ \\
Taxi-3 & Light-duty taxi & Gasoline & Euro 2 & 2003 & 99638 \\
Taxi-4 & Light-duty taxi & Gasoline & Euro 3 & 2007 & 281315 \\
Taxi-5 & Light-duty taxi & Gasoline & Euro 3 & 2008 & 361180 \\
HDDT-1 & Heavy-duty truck & Diesel & Euro 1 & 2003 & 331387 \\
HDDT-2 & Heavy-duty truck & Diesel & Euro 1 & 2003 & 271000 \\
HDDT-3 & Heavy-duty truck & Diesel & Euro 2 & 2004 & 271125 \\
HDDT-4 & Heavy-duty truck & Diesel & Euro 2 & 2004 & 204193 \\
HDDT-5 & Heavy-duty truck & Diesel & Euro 3 & 2009 & 70000 \\
Bus-1 & City bus & Diesel & Euro 2 & 2006 & 295236 \\
Bus-2 & City bus & Diesel & Euro 3 & 2006 & 175122 \\
MT-1 & Motorcycle & Gasoline & Euro 1 & 2003 & 15000 \\
MT-2 & Motorcycle & Gasoline & Euro 1 & 2003 & 11191 \\
MT-3 & Motorcycle & Gasoline & Euro 2 & 2004 & 96969 \\
MT-4 & Motorcycle & Gasoline & Euro 2 & 2003 & 13912 \\
MT-5 & Motorcycle & Gasoline & Euro 2 & 2003 & 5379 \\
\hline & & & & & \\
\hline
\end{tabular}

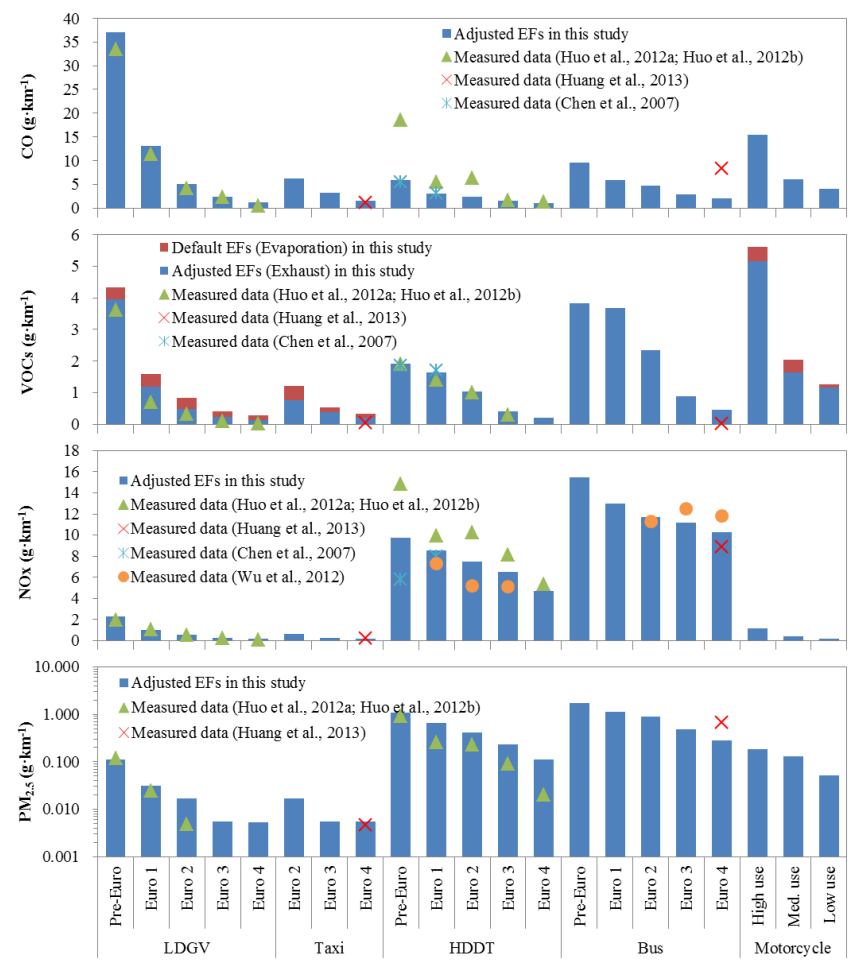

Figure 2. Adjusted emission factors of various vehicle types (blue bars) and their comparisons with measured emission factors in the previous studies (dots). on urban areas with high $\mathrm{NO}_{x}$ concentration (unitless). The yield for each SOA precursor was referenced from Gentner et al. (2012), which listed the yields of known and estimated compounds using a combination of measured SOA yields derived from laboratory-chamber experiments and approximate SOA yields based on box modeling. However, considering the average organic loading in Shanghai $\left(15.5 \mu \mathrm{g} \mathrm{m}^{-3}\right)$ was relatively higher than that in the reference $\left(10 \mu \mathrm{g} \mathrm{m}^{-3}\right)$, we recalculated the SOA yields of the compounds using a semi-empirical model based on absorptive gas-particle partitioning of two semi-volatile products introduced by Odum et al. (1997). The SOA yields of straight alkanes increased by an average of $16 \%$ in the range of 12-17 carbon atoms, C68 aromatics increased by $\sim 19 \%$, and naphthalene increased by $\sim 12 \%$. The yields of the compounds in similar chemical classes were corrected based on the increments above.

\subsection{Air pollution observation and vehicular OA contribution determination}

\subsubsection{Air pollution observation}

To estimate the vehicular OA production in the atmosphere, we calculated the SOA formation potentials from vehicular VOC emissions based on observation data with a photochemical age-based parameterization method. The observation data were obtained from a monitoring site on the roof of a five-floor building ( $15 \mathrm{~m}$ high above the ground) at Shanghai Academy of Environmental Science $\left(31.17^{\circ} \mathrm{N}\right.$, 
$121.43^{\circ} \mathrm{E}$ ), which was located southwest of the urban area of Shanghai. The site was mostly surrounded by commercial properties and residential dwellings. Vehicle exhaust was a major source of pollutants near this site. Figure S1 in the Supplement shows the location of monitoring sites in this study. Carbon monoxide was continuously measured by an ECOTECH EC9820 CO analyzer. $\mathrm{PM}_{2.5}$ concentration was measured by a Thermo Fisher commercial instrument $\beta$-ray particulate monitor. Organic carbon (OC) and elemental carbon (EC) were measured by a carbon analyzer (model RT-4, Sunset Laboratory Inc.). Water-soluble ions were measured by a commercial instrument for online monitoring of aerosols and gases (MARGA, model ADI 2080, Applikon Analytical B.V.). Individual VOC species were continuously measured every $30 \mathrm{~min}$ by two online gas chromatographs with flame ionization detector (GC-FID) systems (Chromato-sud airmoVOC C2-C6 no. 5250308 and airmoVOC C6-C12 no. 2260308, France). Figure S2 shows the time series data of meteorological parameters and concentrations of major air pollutants observed in urban Shanghai in summer (August in 2013) and winter (January in 2013). We did not measure the OA concentration due to the lack of observation equipment. The OA concentrations were determined by OC concentrations multiplied by the OM / OC ratio. Turpin and Lim (2001) suggested a ratio around 1.2-1.6 from fresh emissions to aged air mass in remote area. Considering our study was mainly focused on urban areas where emissions were not fully aged, we used the ratio of 1.4 to convert OC concentrations.

\subsubsection{OA production estimation}

The evolution of primary VOC emissions to SOA formation is determined by $\mathrm{OH}$ exposure in the atmosphere. The $\mathrm{OH}$ exposure can be calculated with Eq. (4) developed by de Gouw et al. (2005, 2008).

$$
\Delta t \cdot[\mathrm{OH}]=\frac{1}{\left(k_{\mathrm{X}}-k_{\mathrm{E}}\right)} \times\left[\ln \left(\left.\frac{[\mathrm{X}]}{[\mathrm{E}]}\right|_{t=0}\right)-\ln \left(\frac{[\mathrm{X}]}{[\mathrm{E}]}\right)\right]
$$

Here, $\Delta t$ is photochemical age $(\mathrm{h}) ;[\mathrm{OH}]$ is the average $\mathrm{OH}$ radical concentrations (molecules $\mathrm{cm}^{-3}$ ). The ratio of $m, p$ xylene to ethylbenzene $(\mathrm{X} / \mathrm{E})$ was considered as a photochemical clock. $k_{\mathrm{X}}$ and $k_{\mathrm{E}}$ are the $\mathrm{OH}$ rate constants of $m$, $p$-xylene $\left(18.9 \times 10^{-12} \mathrm{~cm}^{3}\right.$ molecule $\left.{ }^{-1} \mathrm{~s}^{-1}\right)$ and ethylbenzene $\left(7.0 \times 10^{-12} \mathrm{~cm}^{3}\right.$ molecule $\mathrm{s}^{-1} \mathrm{~s}^{-1}$, Yuan et al., 2013). $[\mathrm{X}] /\left.[\mathrm{E}]\right|_{t=0}$ and $[\mathrm{X}] /[\mathrm{E}]$ are initial emission ratio and the ratio after photochemical reaction of $m, p$-xylene to ethylbenzene. The concentrations of $m, p$-xylene and ethylbenzene showed good correlations during the observations (Fig. S3). The different diurnal variations of $m, p$-xylene and ethylbenzene indicated that they are oxidized at different rates to each other (Fig. S4). Figure 3 illustrates the diurnal distributions of the ratios of observed $m, p$-xylene to ethylbenzene in summer and winter of 2013. The initial emission ratios of $m, p$-xylene to ethylbenzene were determined by the $\mathrm{X}$ / E ratio on 97.5 percentiles, which were 2.17 and 1.68 in summer and winter, respectively.

OA production is determined by the loss terms and formation rates of OA concentration after POA emissions exhaust into the atmosphere. de Gouw et al. (2008) introduced a method to explain the OA evolution during photochemical aging of urban plumes as shown by Eq. (5).

$$
\begin{aligned}
& \frac{\Delta \mathrm{OA}}{\Delta \mathrm{CO}}=\frac{\Delta \mathrm{POA}}{\Delta \mathrm{CO}}+\frac{\Delta \mathrm{SOA}}{\Delta \mathrm{CO}} \\
& =\mathrm{ER}_{\mathrm{POA}} \times \exp \left(-L_{\mathrm{OA}} \cdot \Delta t\right)+\mathrm{ER}_{\mathrm{VOC}_{i}} \times Y_{\mathrm{OA}_{i}} \\
& \times \frac{P_{\mathrm{OA}}}{L_{\mathrm{OA}}-P_{\mathrm{OA}}} \times\left[\exp \left(-P_{\mathrm{OA}} \cdot \Delta t\right)\right. \\
& \left.-\exp \left(-L_{\mathrm{OA}} \cdot \Delta t\right)\right]
\end{aligned}
$$

Here, $\triangle \mathrm{OA} / \triangle \mathrm{CO}$ is the ratio of $\mathrm{OA}$ formation versus $\mathrm{CO}$ emissions after photochemical reaction $\left(\mu \mathrm{g} \mathrm{m}^{-3} \mathrm{ppmv}^{-1}\right)$. $\mathrm{ER}_{\mathrm{POA}}$ is the primary emission ratio of OA to $\mathrm{CO}$ emissions $\left(\mu \mathrm{g} \mathrm{m}^{-3} \times \mathrm{ppmv}^{-1}\right)$. ER $\mathrm{VOCj}_{\mathrm{j}}$ is the primary emission ratio of VOC (including SOA precursors and unidentified species) from source $j$ to $\mathrm{CO}$ emissions in the unit of $\mathrm{ppbv}^{-1} \mathrm{ppmv}^{-1} . Y_{j}$ is the SOA yield of source $j$, which is determined by Eq. (3). $L_{\mathrm{OA}}$ and $P_{\mathrm{OA}}$ are the loss and formation rate of organic aerosol, respectively. We used the empirical parameters derived by de Gouw et al. (2008), which were 0.00677 and $0.0384 \mathrm{~h}^{-1}$, respectively. $\Delta t$ is the photochemical age calculated by Eq. (4). Because there is no $\mathrm{OH}$ measurement in Shanghai, we reference the $24 \mathrm{~h}$ average $\mathrm{OH}$ concentration $\left(3 \times 10^{6}\right.$ molecules $\left.\mathrm{cm}^{-3}\right)$ from de Gouw et al. (2008).

\subsubsection{Determination of vehicular OA contribution}

The observed $\triangle \mathrm{OA} / \triangle \mathrm{CO}$ in the atmosphere represents the ratio of total POA emissions and their SOA formation to total $\mathrm{CO}$ emissions from all sources, which can be explained by Eq. (6) as follows.

$$
\begin{aligned}
& \left(\frac{\Delta \mathrm{OA}}{\Delta \mathrm{CO}}\right)_{\mathrm{obs}}=\frac{\mathrm{POA}_{\text {total }}+\mathrm{SOA}_{\text {total }}}{\mathrm{CO}_{\text {total }}} \\
& =\frac{\left(\mathrm{POA}_{\mathrm{veh}}+\mathrm{SOA}_{\mathrm{veh}}\right)}{\mathrm{CO}_{\text {total }}}+\frac{\left(\mathrm{POA}_{\mathrm{oth}}+\mathrm{SOA}_{\mathrm{oth}}\right)}{\mathrm{CO}_{\text {total }}} \\
& =\frac{\mathrm{OA}_{\mathrm{veh}}}{\mathrm{CO}_{\text {total }}}+\frac{\mathrm{OA}_{\mathrm{oth}}}{\mathrm{CO}_{\text {total }}}
\end{aligned}
$$

The contribution of vehicular OA to total OA production in the atmosphere can be determined by the ratio of $\mathrm{OA}_{\mathrm{veh}} / \mathrm{CO}_{\text {total }}$ to $(\Delta \mathrm{OA} / \mathrm{m} \Delta \mathrm{CO})_{\mathrm{obs}}$. Here, $(\triangle \mathrm{OA} / \triangle \mathrm{CO})_{\mathrm{obs}}$ is the ratio of observed $\triangle \mathrm{OA}(\mathrm{Obs}, \mathrm{OA}-$ $\left.\mathrm{OA}_{\text {background }}\right)$ to observed $\triangle \mathrm{CO}\left(\mathrm{Obs}, \mathrm{CO}-\mathrm{CO}_{\text {background }}\right)$ in the unit of $\mu \mathrm{g} \mathrm{m}^{-3} \mathrm{ppmv}^{-1}$. $\mathrm{OA}_{\mathrm{veh}} / \mathrm{CO}_{\text {total }}$ is the ratio of vehicular POA emissions and SOA formation to total $\mathrm{CO}$ emissions, which can be calculated by Eq. (5). ER POA $_{\text {and }}$ $\mathrm{ER}_{\mathrm{VOC}_{\mathrm{C}}}$ in Eq. (5) represent the ratios of vehicular POA and VOC emissions to total $\mathrm{CO}$ emissions from vehicles 

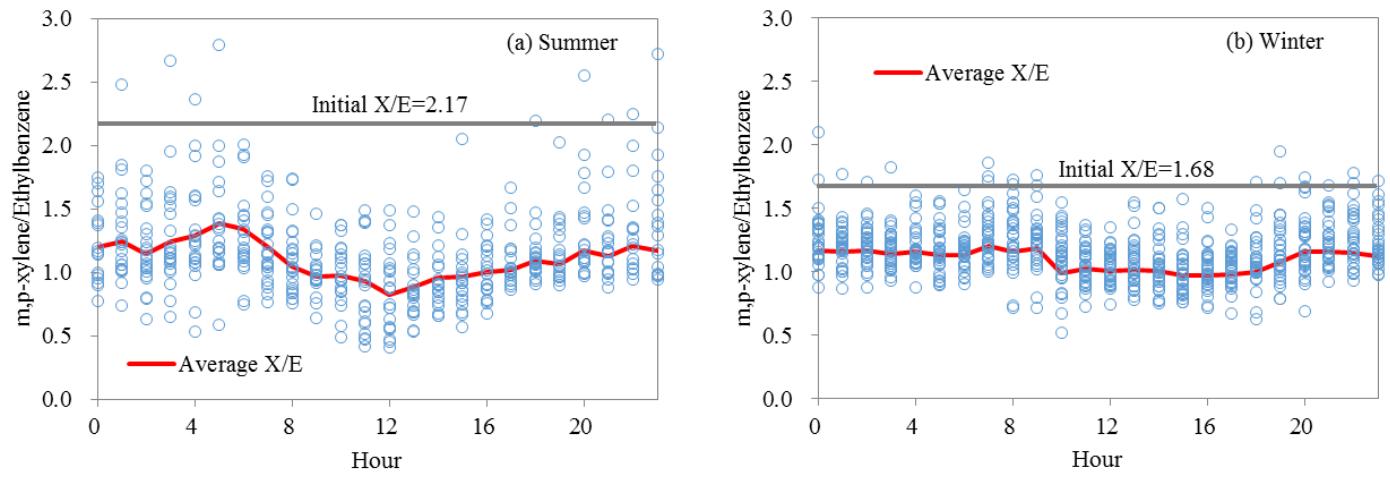

Figure 3. Diurnal distributions of the ratios of $m, p$-xylene to ethylbenzene concentrations in summer and winter in the urban atmosphere in 2013.

and other sources. The total amount of $\mathrm{CO}$ emissions was $1.2 \times 10^{6}$ tons according to the annually updated emission inventory in Shanghai for the year of 2012. Iron and steel manufacturing was the major source of $\mathrm{CO}$ emissions, which accounted for $54 \%$ of the total. The sector produced $19.7 \times 10^{6}$ and $18 \times 10^{6}$ tons of pig iron and crude steel, and consumed more than $10 \times 10^{6}$ tons of coal in 2012. Vehicles were the second largest source, accounting for $27.8 \%$ of the total. However, considering the observation site was located in the urban area and most of the industrial CO emission sources were located in the surrounding areas (about 30$50 \mathrm{~km}$ from the city center), it would be more reasonable to simulate the contribution of $\mathrm{CO}$ concentration from vehicle exhausts and other sources to the receptor by using a numerical model. Here we used the CMAQ model and brute-force method to simulate the $\mathrm{CO}$ concentrations during January and August in 2013 under two scenarios of with or without vehicular $\mathrm{CO}$ emissions. The meteorological data was from the results of the Weather Research and Forecasting Model (WRF). Detailed information is shown in the supplement materials. The results showed that vehicles dominated $\mathrm{CO}$ emissions in urban Shanghai, accounting for 66 and $70 \%$ of total $\mathrm{CO}$ concentrations in summer and winter, respectively. On this account, the vehicular fraction of total $\mathrm{CO}$ emissions used in this study was determined to $68 \%$.

\section{Results and discussion}

\subsection{Vehicle emission inventory}

The emissions of $\mathrm{CO}, \mathrm{NO}_{x}$, VOCs, EVA (gas evaporation), $\mathrm{EC}$, and POA $(\mathrm{OC} \times 1.2)$ from vehicles were 343.9, 110.9, 39.4, 8.9, 4.0, and $4.3 \mathrm{k}$ tons in Shanghai for the year of 2012 (See Table 3). Gasoline vehicles (including LDGV, taxis, HDGV, and motorcycles) were the major sources of CO, VOCs, and EVA emissions, accounting for 91, 69, and $100 \%$, respectively. Diesel vehicles (including LDDV, $\mathrm{HDDV}$, and buses) were the major source of $\mathrm{NO}_{x}, \mathrm{EC}$, and
POA emissions, comprising 82, 99, and $96 \%$, respectively. $\mathrm{CO}$ and VOC (including EVA) emissions decreased by 40 and $38 \%$ compared with the results for the year of 2004 from Wang et al. (2008). $\mathrm{NO}_{x}$ emissions increased by $21 \%$. $\mathrm{PM}$ emissions were estimated low in that study, since the PM emission factors were much lower than real-world measurement data, as shown in Fig. 2. Gasoline vehicle emissions have been well controlled even though their VKTs have nearly doubled in the past few years. In comparison, the control effect of diesel vehicle emissions was relatively poor. It is clear that diesel exhausts dominate the primary PM (including EC and OA) emissions in Shanghai. However, since VOC emissions are mainly from gasoline vehicles, we will further discuss the contributions of gasoline and diesel exhausts to SOA.

\subsection{VOC species of vehicle emissions and gas evaporation}

Figure 4 compares the VOC compositions of the exhausts from different vehicle types and gas evaporation in this study to the results from other countries or regions. Since the VOC species measured in different studies are not the same, we normalized the concentrations of the common species including $\mathrm{C} 2-\mathrm{C} 12$ alkanes, alkenes, alkynes, and single-ring aromatics in each study as $100 \%$. Other compounds and unidentified VOCs were excluded in the comparison. The weighted percentages of individual VOC for the exhausts from different vehicle types and gas evaporation were listed in Table S1 in the Supplement.

The exhausts from gasoline vehicles (including LDGVs and taxis) had similar VOC compositions. Single-ring aromatics were the major species of the exhausts from gasoline vehicles, approximately accounting for $50 \%$ of the total VOCs. Straight-chain alkanes, branched alkanes, and cycloalkanes comprised $17.0,18.1$, and $6.1 \%$ of the total VOCs, respectively. Toluene, $m, p$-xylene, o-xylene, and ethylbenzene were the main compounds in LDGV and taxi exhausts, accounting for $7.54,6.71,5.20$, and $4.42 \%$ 
Table 3. Vehicle emission inventory in Shanghai.

\begin{tabular}{lrrrrrr}
\hline & \multicolumn{7}{c}{ Emission inventory (k ton) } \\
\cline { 2 - 7 } Vehicle type & $\mathrm{CO}$ & $\mathrm{NO}_{x}$ & VOCs & EVA & EC & $\begin{array}{r}\text { POA } \\
\text { (OC } \times 1.2)\end{array}$ \\
\hline In vehicle type: & & & & & & \\
LDGV & 192.03 & 13.30 & 15.59 & 6.15 & 0.02 & 0.07 \\
LDDV & 1.89 & 5.72 & 0.32 & 0.00 & 0.17 & 0.11 \\
Taxi & 68.89 & 3.86 & 5.56 & 1.96 & 0.01 & 0.03 \\
HDGV & 36.79 & 2.20 & 2.29 & 0.29 & 0.00 & 0.01 \\
HDDV & 24.71 & 67.56 & 9.74 & 0.00 & 3.16 & 3.40 \\
Bus & 5.53 & 17.56 & 2.06 & 0.00 & 0.58 & 0.62 \\
Motorcycle & 14.01 & 0.67 & 3.85 & 0.49 & 0.02 & 0.06 \\
In fuel type: & & & & & & \\
Gasoline & 311.71 & 20.04 & 27.28 & 8.88 & 0.05 & 0.17 \\
Diesel & 32.14 & 90.84 & 12.12 & 0.00 & 3.91 & 4.13 \\
Total & 343.85 & 110.88 & 39.40 & 8.88 & 3.96 & 4.30 \\
\hline
\end{tabular}

of the total VOCs, respectively. Motorcycles emitted more branched alkanes and a lower rate of single-ring aromatics than LDGVs and taxis. 2-methylhexane (23.43\%) was the most abundant VOC in motorcycle exhausts, followed by $m$, p-xylene $(9.34 \%)$, ethylbenzene $(5.53 \%)$ and $o$-xylene $(4.37 \%)$. It was indicated from Fig. 3 that the proportion of single-ring aromatics in LDGV exhausts was higher and the proportion of alkenes was lower in this study and previous studies in China (Liu et al., 2008; Wang et al., 2013) than those in Hong Kong (Guo et al., 2011) and the US (Schauer et al., 2002; Gentner et al., 2013; May et al., 2014). The differences of aromatic content in gasoline fuel in different regions and countries could be the main reason of the difference in the proportion of aromatic compounds in LDGV exhausts. The limit of aromatic content in current gasoline standards in China was 40 vol \%, which was much higher than the limits of gasoline standards of the US (22-25 vol \%) and Europe (35 vol \%).

A high proportion of straight-chain alkanes was measured in the exhausts from diesel vehicles, which accounted for 34.9 and $35.6 \%$ of the total VOCs from HDDT and bus exhausts, respectively. N-dodecane, propene, $\mathrm{n}$-undecane, acetone, and n-decane were major species in diesel exhausts, accounting for $13.65,10.85,8.69,7.00$, and $6.86 \%$ of the total VOCs, respectively. The proportions of straight-chain alkanes in diesel exhausts in this study were much higher than those in the previous studies of the US (Schauer et al., 1999; May et al., 2014). Incomplete combustion of diesel fuel caused by poor engine maintenance could be the main reason for the high straight-chain alkane emissions.

High proportion of alkenes was measured in gas evaporation in this study, which accounted for $40 \%$ of the total VOCs. Propane, isopentane, isobutene, 1-pentene, and nbutane were major species in gas evaporation emissions, accounting for $15.99,11.87,9.69,8.87$, and $6.51 \%$ of the to- tal VOCs, respectively. The proportions of VOC species in gas evaporation in this study were close to the results in the other study in China (Zhang et al., 2013), but different from the studies in the US (Harley et al., 2000) and Korea (Na et al., 2004), which reported fewer alkenes and more branched alkanes in gas evaporation.

\subsection{SOA yields of different vehicle exhausts and gas evaporation}

VOC species of vehicle emissions and gas evaporation were classified into five categories by their chemical classes, and their distributions of carbon numbers were shown in Fig. 5a. Previous studies have confirmed that IVOCs, which were not detected in this study, played important roles to SOA production (Jathar et al., 2013; Zhao et al., 2014). For this reason, we introduced the amounts of alkanes and aromatic larger than $\mathrm{C} 12$ and polycyclic aromatics in unburned fuels from Gentner et al. (2012) as the inferred S/IVOCs as shown in the light-colored bars in Fig. 5a. The carbon numbers of VOCs in gasoline and motorcycle exhausts mainly concentrated in the intervals between $\mathrm{C} 6$ to $\mathrm{C} 9$, whether the IVOCs were merged or not. Comparatively, exhausts from diesel vehicles had a wider distribution of carbon number, ranging from $\mathrm{C} 2$ to $\mathrm{C} 25$. More than half of the species were S/IVOCs and most of them were alkanes. The carbon numbers of VOCs in gas evaporation were mainly distributed within the range of $\mathrm{C} 3$ C7, which were much smaller than those in vehicle exhausts.

Figure 5b shows the SOA mass yields of different chemical class. To compare the differences of the SOA yields with or without S/IVOC species, we set two scenarios as "Y1" and "Y2". Y1 indicates the SOA yields of measured C2$\mathrm{C} 12$ VOCs in this study. Y2 includes the extra SOA yields of inferred S/IVOCs. S/IVOC species had little effect on the SOA yields of gasoline exhausts and evaporative emissions. Aromatics dominated the yields which accounted for almost 


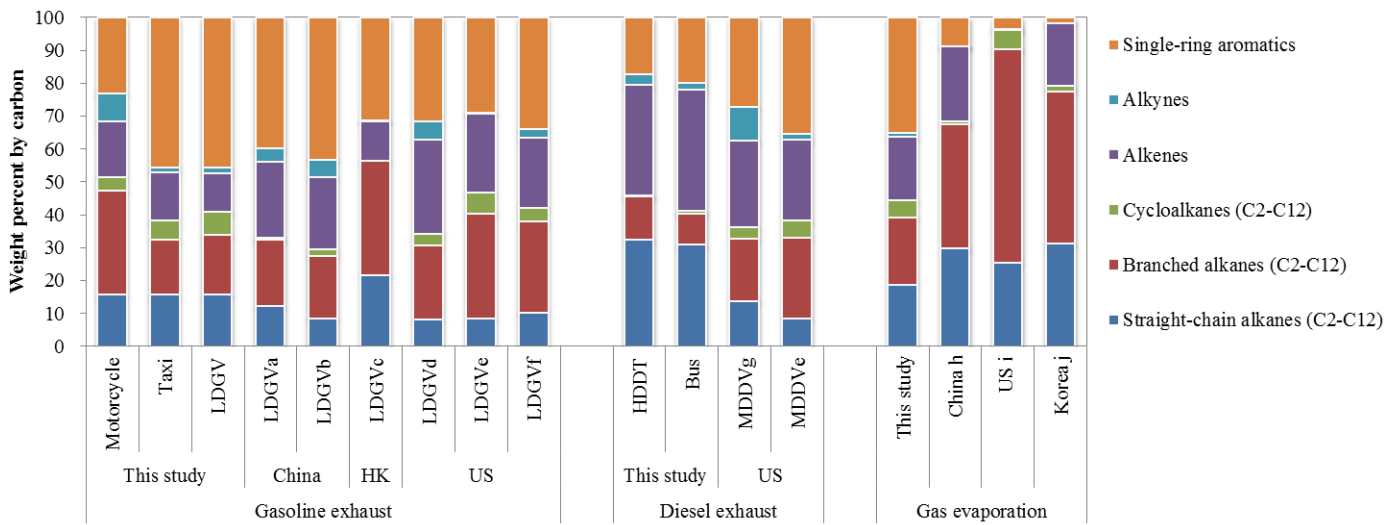

Figure 4. Comparisons of measured VOC compositions of the exhausts from different vehicle types and gas evaporation to the results in other studies (a. Liu et al., 2008; b. Wang et al., 2013; c. Guo et al., 2011; d. Schauer et al., 2002; e. May et al., 2014; f. Gentner et al., 2013; g. Schauer et al., 1999; h. Zhang et al., 2013; i. Harley et al., 2000; j. Na et al., 2004).

$100 \%$ of the total. However, the SOA yield of diesel exhaust was significantly affected by S/IVOCs. The yield increased from 0.010 to 0.191 when the inferred S/IVOCs were considered. In the Y2 scenario, aromatics were still the largest contributors $(34.9 \%)$ to - but not dominating - the yield. Next were branched alkanes, polycyclic aromatics, and straightchain alkanes, which accounted for $24.8,17.1$, and $12.7 \%$.

The SOA yield of gasoline exhaust was larger than the yield of liquid gasoline reported by Gentner et al. (2012). We found the aromatic contents in gasoline exhausts of this study which dominated the SOA yield were much higher than those in the reference. This may be due to the loose limit of aromatics for the gasoline fuel in China. However, the estimated yield of gasoline exhaust was much lower than the effective yields (3-30\%) of LEV-1 (tier 1 of low emission vehicle standards in California, US) gasoline vehicles (similar to Euro 1-3 LDGVs tested in this study) investigated using a smog-chamber experiment by Gordon et al. (2014a). The reason for the underestimation was still unclear. In contrast, the estimated SOA yield of diesel exhaust which combined the inferred S/IVOCs (Y2) was higher than the average effective yields $(9 \pm 6 \%)$ for HDDVs without DPF based on smogchamber experiments by Gordon et al. (2014b). Since there were few experiments on motorcycle exhausts, we compared the SOA yield of motorcycle exhausts with the experiment results from the exhausts of 2- and 4-stroke gasoline off-road engines (Gordon et al., 2013). Neither motorcycles nor offroad engines had catalytic converters. The estimated yield was close to the experiment results of off-road engine exhausts $(2-4 \%)$.

\subsection{Primary emission ratio and SOA formation potential based on observation}

Figure 6 is a scatter plot of OA versus CO concentrations measured in urban Shanghai in the summer and the winter of 2013. The observation data were color-coded by $\mathrm{OH}$
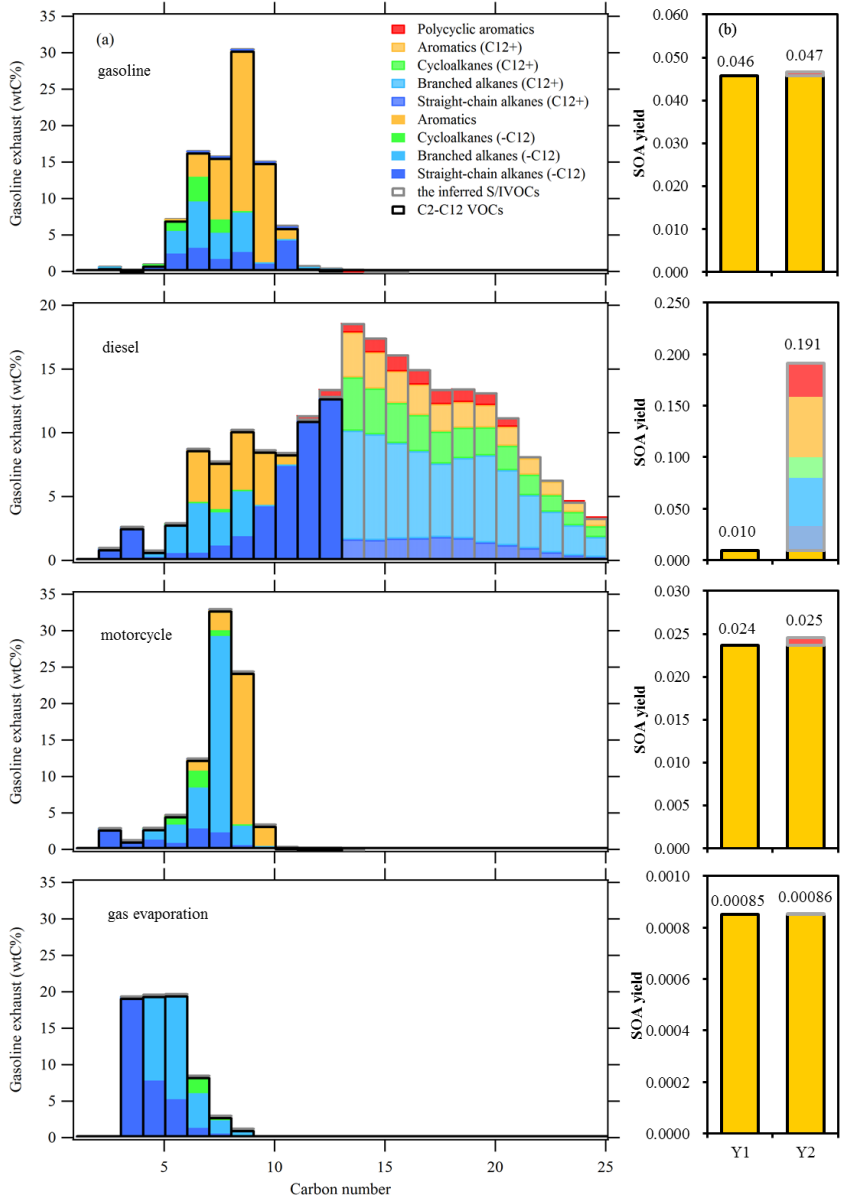

Figure 5. (a) Distributions of mass by chemical class in carbon number of different vehicle exhausts and evaporative emissions; (b) calculated SOA yields based on $\mathrm{C} 2-\mathrm{C} 12$ VOCs measured in this study (Y1) and C2-C12 VOCs plus the inferred S/IVOC species (Y2). The inferred S/IVOC species are shown in light-colored bars. 

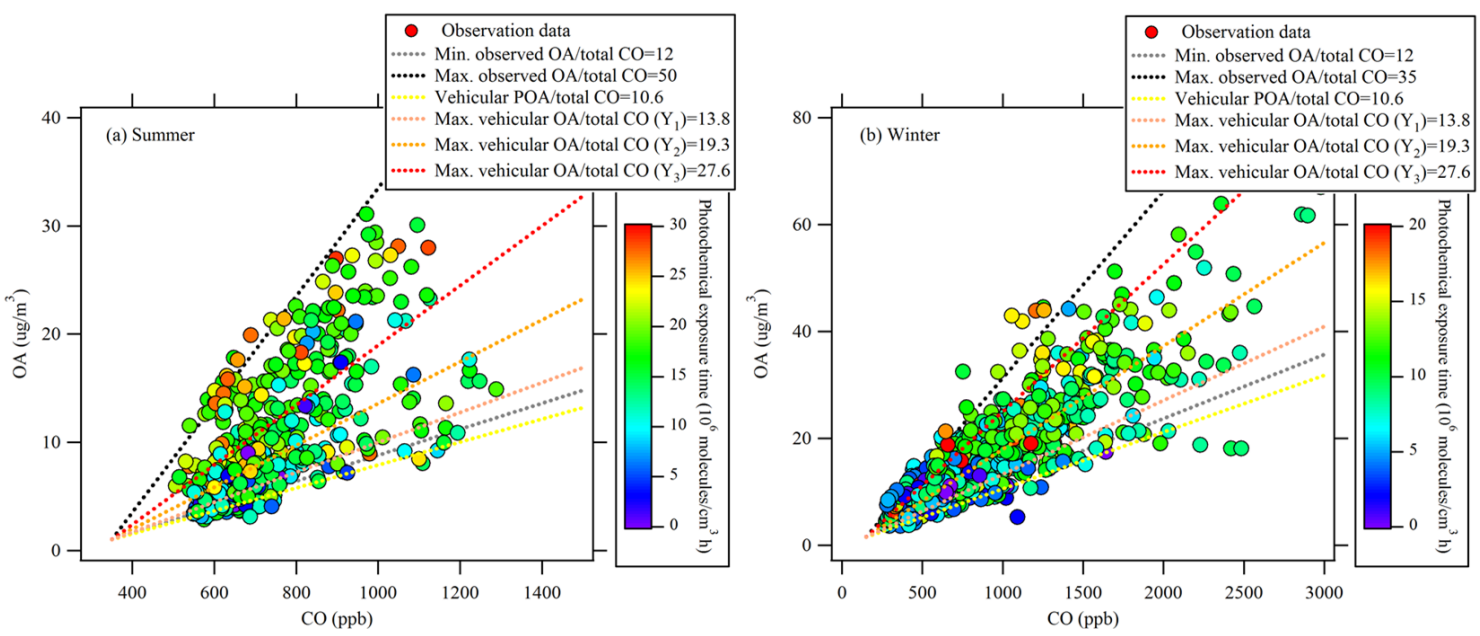

Figure 6. Relationship of measured OA and CO concentrations color-coded by the photochemical exposure in the summer (a) and winter (b) of 2013 in urban Shanghai according to Eq. (4). Minimum and maximum ratios of observed OA to CO concentrations are shown by dotted gray and black lines. Vehicular POA/total CO is shown by the dotted yellow line. The minimum and maximum OA formation ratios of vehicle emissions calculated with three different SOA yields of Y1, Y2 and Y3 are shown by the dotted pink, orange, and red lines, respectively.

exposure $(\Delta t \times[\mathrm{OH}])$ determined by Eq. (4). It was indicated from the figure that the ratios of OA to $\mathrm{CO}$ concentrations generally showed growing trends with the increase of $\mathrm{OH}$ exposure both in summer and winter. The results were similar to the previous studies in the United States, Japan, and Mexico (Bahreini et al., 2012; de Gouw et al., 2008; Takegawa et al., 2006; DeCarlo et al., 2008). The primary emission ratios of POA to $\mathrm{CO}$ were determined by the minimum slopes of the observed OA to CO concentrations, about $12 \mu \mathrm{g} \mathrm{m}^{-3} \mathrm{ppmv}^{-1}$ in both summer and winter (as shown by the dotted gray lines). The maximum slopes of OA to $\mathrm{CO}$ were 50 and $35 \mu \mathrm{g} \mathrm{m}^{-3}$

,ppmv ${ }^{-1}$ (as shown by the dotted black lines) in summer and winter, respectively. The SOA formation ratio in summer was much higher than in winter. The inventorybased vehicular POA emissions to total $\mathrm{CO}$ emissions was $10.6 \mu \mathrm{g} \mathrm{m}^{-3} \mathrm{ppmv}^{-1}$ in the urban area of Shanghai (shown by the dotted yellow lines), close to the primary emission ratio observed in the atmosphere, which indicated that vehicles dominated the POA emissions in urban Shanghai. The dotted pink and orange lines in Fig. 6 represent the maximum OA production ratios (assuming SOA precursors were $100 \%$ reacted) calculated with the SOA yields in Y1 (only detected VOCs in this study) and Y2 scenarios (detected VOCs plus the inferred S/IVOCs). The maximum OA production ratios were 13.8 and $18.7 \mu \mathrm{g} \mathrm{m}^{-3} \mathrm{ppmv}^{-1}$, respectively. It was indicated that S/IVOCs played a much more important role in SOA production of vehicle exhaust. However, the maximum OA production ratio for the $\mathrm{Y} 2$ scenario was still considerably underestimated compared with the observation data, which implied that the SOA yields derived by known and estimated species were still far from explaining the actual SOA formation rate in the atmosphere. For this reason, we introduced the measured SOA yield of gasoline exhaust $(\sim 0.190)$ from Gordon et al. (2014a) to substitute the yield for gasoline vehicles (0.039) in the Y2 scenario and defined the new group as the Y3 scenario. The maximum OA production ratio (shown by the dotted red lines) increased to $27.6 \mu \mathrm{g} \mathrm{m}^{-3} \mathrm{ppmv}^{-1}$, but still failed to reach the maximum observed $\triangle \mathrm{OA} / \Delta \mathrm{CO}$. There must be other emission sources of SOA precursors in the atmosphere of Shanghai. Previous studies have revealed that VOC emissions from solvent usage, chemical and petrochemical industrial, and coal burning, etc. comprised more than $70 \%$ of the observed VOCs in the atmosphere of urban Shanghai (Cai et al., 2010; Wang et al., 2013). The SOA production of VOC emissions from these sources cannot be ignored.

\subsection{Estimation of vehicular OA contribution in the urban atmosphere}

Figure 7 shows the diurnal variations of average observed $\Delta \mathrm{OA} / \Delta \mathrm{CO}$ and $\mathrm{OH}$ exposure in summer and winter. There was a strong correlation between the observed $\Delta \mathrm{OA} / \Delta \mathrm{CO}$ and $\mathrm{OH}$ exposure, which indicated that the photooxidation dominated the SOA formation in the atmosphere. In the role of photochemical reaction, the observed $\Delta \mathrm{OA} / \Delta \mathrm{CO}$ showed a rapid growth trend in the afternoon in summer and reached a peak around 13:00-14:00 local time. The average observed $\triangle \mathrm{OA} / \triangle \mathrm{CO}$ in urban atmosphere of Shanghai were 33.2 and $21.1 \mathrm{\mu g} \mathrm{m}^{-3} \mathrm{ppmv}^{-1}$ in summer and winter, respectively.

To evaluate the contribution of vehicle emissions to OA production in the urban atmosphere, we estimated the vehicular OA formation ratio to total $\mathrm{CO}$ emissions with Eq. (5) 

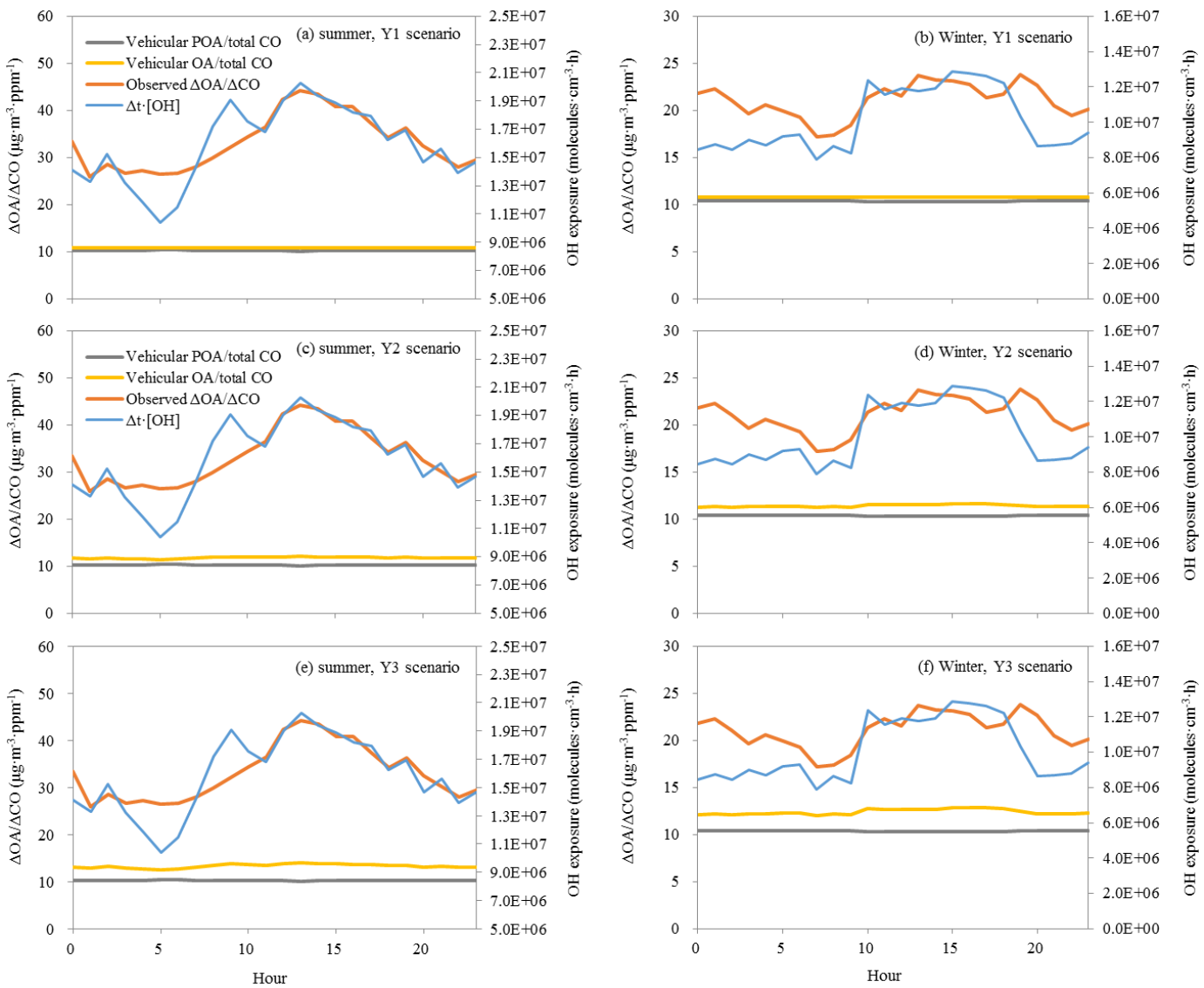

Figure 7. Diurnal variations of observed $\triangle \mathrm{OA} / \Delta \mathrm{CO}$ in the atmosphere (red line), $\mathrm{OH}$ exposures (blue line), and the ratios of vehicular POA emissions (gray line) and OA formation (orange line) to total CO emissions with the SOA yields in three scenarios (Y1, Y2, and Y3) in summer and winter in the urban area of Shanghai for the year of 2013.

in three scenarios. Figure 7a and $b$ showed the results of vehicular OA formation ratios to total $\mathrm{CO}$ emissions in the $\mathrm{Y} 1$ scenario. The SOA yields of gasoline, diesel, and motorcycle exhausts and gas evaporation were 0.046, 0.010, 0.024, and 0.0009 , respectively. Figure $7 \mathrm{c}$ and $\mathrm{d}$ showed the results in the Y2 scenario where the inferred S/IVOCs were merged. The SOA yields of gasoline, diesel, and motorcycle exhausts and gas evaporation were $0.047,0.191,0.025$, and 0.0009 , respectively. Figure $7 \mathrm{e}$ and $\mathrm{f}$ showed the results in the Y3 scenario. The SOA yield of gasoline exhaust was replaced to 0.190 , based on the experiment by Gordon et al. (2014a). The photochemical age $(\Delta t)$ in each hour was calculated with Eq. (4). Due to the lack of $\mathrm{OH}$ measurements in Shanghai, we referenced the $24 \mathrm{~h}$ average $\mathrm{OH}$ concentration $\left(3 \times 10^{6}\right.$ molecules $\left.\mathrm{cm}^{-3}\right)$ from de Gouw et al. (2008). The gray and yellow lines show the ratio of vehicular POA and OA production to total $\mathrm{CO}$ emissions. The average vehicular OA production ratios to total $\mathrm{CO}$ emissions in the urban area were 10.6 and $10.8 \mu \mathrm{g} \mathrm{m}^{-3} \mathrm{ppmv}^{-1}$ in summer and winter in the $\mathrm{Y} 1$ scenario, 11.8 and $11.4 \mu \mathrm{g} \mathrm{m}^{-3} \mathrm{ppmv}^{-1}$ in the $\mathrm{Y} 2$ scenario, and 13.3 and $12.4 \mu \mathrm{g} \mathrm{m}^{-3} \mathrm{ppmv}^{-1}$ in the Y3 scenario. The vehicular OA mass accounted for 34 and
$52 \%$ of the average observed OA in summer and winter in the urban atmosphere of Shanghai in the Y1 scenario. The contributions increased to 37 and $55 \%$ in the $\mathrm{Y} 2$ scenario, and 41 and $59 \%$ in the Y3 scenario. It was indicated that vehicle emissions were the major source of OA mass in the urban atmosphere of Shanghai. For the Y2 scenario where the inferred IVOC species were merged to SOA yield estimation, the vehicular OA production ratios increased by about $3 \%$. For the Y3 scenario where the SOA yield of gasoline exhausts was enhanced to the smog-chamber experiment result (0.190), the vehicular OA production ratios further increased by about $4 \%$. Vehicular SOA formation ratios accounted for $4 \%$ of the total vehicular OA in the Y1 scenario, $9-13 \%$ in the $\mathrm{Y} 2$ scenario, and $16-23 \%$ in the $\mathrm{Y} 3$ scenario. The SOA formation ratios in both scenarios were lower than expected. There were two possible reasons for the underestimation. One reason was that other emission sources with high SOA formation potentials in addition to vehicles were not considered in this study. The non-fossil VOC emissions from solvent use, chemical and petrochemical industries etc. reported by previous studies could be the rest of the contributors (Cai et al., 2010; Wang et al., 2013). Another possible 

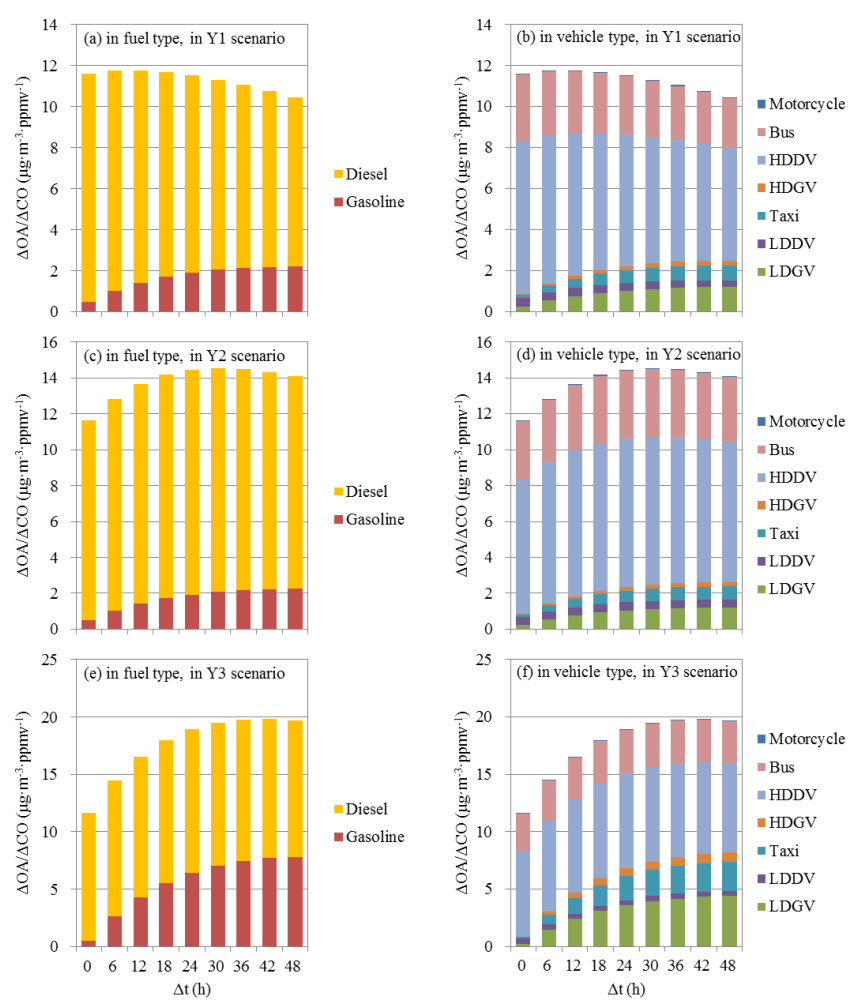

Figure 8. Contributions of vehicle emissions to OA formation ratios in different vehicle and fuel types in $\mathrm{Y} 1, \mathrm{Y} 2$ and $\mathrm{Y} 3$ scenarios with the changes of photochemical ages.

reason was that the SOA yields were still underestimated in this study. There were about 30,50 , and $15 \%$ of VOC species still unidentified in gasoline, diesel, and motorcycle exhausts even after we combined the inferred S/IVOC species reported in Gentner et al. (2012). The SOA formation potentials of the identified VOC species may contribute more SOA than expected.

At present, few SOA observations in the cities of China can be referenced to verify the results in this study. Huang et al. (2014) have reported that the fossil OA dominated the OA mass $(\sim 40 \%)$ in Shanghai based on the observation data in the first quarter of 2013, which was slightly lower than our result. The possible reason for the difference could be the location of the observation site (close to urban or suburban). However, the studies both indicated that vehicle emissions were the major source of OA mass in large cities of China.

\subsection{SOA formation contributions of different vehicle types}

Figure $8 \mathrm{a}$ and $\mathrm{b}$ show the changes of OA formation ratios in different fuel and vehicle types in the Y1 scenario with the increase of the photochemical age. The OA produced from evaporative emissions were combined in gasoline vehicles and corresponding vehicle types. The inventory-based $\Delta \mathrm{OA} / \triangle \mathrm{CO}$ show downward trends in the Y1 scenario.
Diesel exhausts dominated OA production, which accounted for 96,91 and $84 \%$ after 0,6 , and $24 \mathrm{~h}$ of photochemical reaction. HDDV and bus emissions were major sources of $\mathrm{OA}$ production. Figure $9 \mathrm{c}$ and $\mathrm{d}$ show the changes of $\mathrm{OA}$ formation ratios in the Y2 scenario. The $\triangle \mathrm{OA} / \triangle \mathrm{CO}$ show upward trends in the Y2 scenario. The contributions of diesel exhausts in this scenario increased to 92 and $87 \%$ after 6 and $24 \mathrm{~h}$ of photochemical reactions. Figure $9 \mathrm{e}$ and $\mathrm{f}$ show the changes of OA formation ratios in the Y3 scenario. The contribution of gasoline vehicles in this scenario increased a lot. Although gasoline vehicles only accounted for $4 \%$ of POA emissions, their contributions to vehicular OA formation increased to 18 and $34 \%$ after 6 and $24 \mathrm{~h}$ of photochemical reactions, respectively. LDGV is the second large contributor after HDDV. It can be indicated that diesel vehicles were the largest contributors to vehicle-derived OA in both scenarios although they only accounted for less than $20 \%$ of VKTs in Shanghai. Control of the POA emissions and SOA precursors from diesel vehicles are equally important. Gasoline vehicle could be another important contributor to vehicular OA formation. However, some debates on the SOA yield of gasoline exhaust still exist. It will be meaningful to find out their actual SOA yield and key precursors for urban OA pollution control.

\section{Conclusions}

To evaluate the OA contribution of vehicle emissions in the urban atmosphere of Shanghai, we developed a vehicular emission inventory and estimated the SOA yields of gasoline, diesel, and motorcycle exhausts and gas evaporation based on measured C2-C12 VOC species and inferred S/IVOC species based on Gentner et al. (2012). Higher contents of aromatics were measured in this study and other studies in China compared with the results from the US and Europe. A loose limit on aromatic contents in the standard of gasoline fuel in China should be responsible for the high aromatic contents, which resulted in a larger SOA yield of gasoline exhausts than the results reported by Gentner et al. (2012) based on the same method. However, the estimated yield was still much lower than the results from smog-chamber experiments (Gordon et al., 2014a), which implied that the unidentified species were considerably contributing to SOA formation.

Vehicles dominated the POA emissions and OA production in the urban atmosphere of Shanghai. Their contributions to OA production were about 40 and $60 \%$ in summer and winter, respectively. The rest of the contributors could be the non-fossil VOC emissions from solvent use, chemical and petrochemical industrials, etc. and the underestimated SOA production from unidentified VOC or IVOC species in the exhaust. At present, vehicles are experiencing rapid growth trends in the cities of China. Primary emissions and secondary formation of OA derived from vehicles will lead to further deterioration of fine particle pollution in the ur- 
ban area. Reduction of primary PM emissions and SOA precursors from vehicle exhausts will be helpful to improve the air quality in the cities of China. The results also indicate that diesel exhausts dominate the POA emissions in the urban area. Therefore, strengthening the primary PM emission control of diesel vehicles, especially for the older diesel vehicles with loose emission standards, as shown by Fig. 2, plays an important role in OA pollution prevention. Now China is conducting the large-scale elimination of "yellow-labeled" diesel vehicles whose emission standards were lower than Euro 3. It can be expected that the OA pollution caused by diesel vehicles will be effectively reduced. On the other hand, gasoline exhausts have high potential impacts on SOA formation in the urban area. Tightening the limit of aromatic contents in gasoline fuel will be meaningful to reduce the SOA contributions of gasoline vehicles.

There are still some uncertainties that need to be improved upon in the future. First is the SOA mass yield. More experiments on SOA yields of vehicle exhausts in China will be helpful to the SOA formation potentials of different vehicle types. Especially for gasoline exhausts, the estimated SOA yield was much lower than the experiment results in the US. Vehicular OA contributions will increase about 4$5 \%$ if we replace the estimated SOA yield of gasoline exhaust to the experiment result. It will be meaningful to find out their actual SOA yield and key precursors for urban OA pollution control. The emission inventory is another important source of uncertainty in this study. To reduce the uncertainty of the vehicular emission inventory, we localized the vehicle mileage and emission factor data based on traffic surveys in Shanghai and real-world measurements in some cities of China. However, the $\mathrm{CO}$ emission inventories of other sources shown in Fig. S5 still have large uncertainties according to the previous study (Huang et al., 2011). A more accurate emission inventory will be helpful to reduce the uncertainty of vehicular OA contribution in this study. However, it can be concluded that vehicle emissions are the most important contributors to OA pollution in the cities of China. Another implication is the potential role of IVOCs in vehicle exhausts, which are very important in SOA formation in urban areas. Therefore, further studies need to pay more attention to determine the contributions of IVOC emissions to OA pollution in China.

\section{The Supplement related to this article is available online at doi:10.5194/acp-15-11081-2015-supplement.}

Acknowledgements. This study was supported by the National Key Technology R\&D Program via grant no. 2014BAC22B03, Chinese Academy of Sciences Strategic Priority Research Program via grant no. XDB05020302, the Science and Technology Commission of Shanghai Municipality Fund Project via grant no. 14DZ1202905, and the Shanghai Natural Science Foundation via grant no. 15ZR1434700.

Edited by: J. Liggio

\section{References}

Bahreini, R., Middlebrook, A. M., de Gouw, J. A., Warneke, C., Trainer, M., Brock, C. A., Stark, H., Brown, S. S., Dube, W. P., Gilman, J. B., Hall, K., Holloway, J. S., Kuster, W. C., Perring, A. E., Prévôt, A. S. H., Schwarz, J. P., Spackman, J. R., Szidat, S., Wagner, N. L., Weber, R. J., Zotter, P., and Parrish, D. D.: Gasoline emissions dominate over diesel in formation of secondary organic aerosol mass, Geophys. Res. Lett., 39, L06805, doi:10.1029/2011GL050718, 2012.

Borbon, A., Gilman, J. B., Kuster, W. C., Grand, N., Chevaillier, S., Colomb, A., Dolgorouky, C., Gros, V., Lopez, M., Sarda-Esteve, R., Holloway, J., Stutz, J., Petetin, H., McKeen, S., Beekmann, M., Warneke, C., Parrish, D. D., and de Gouw, J. A.: Emission ratios of anthropogenic volatile organic compounds in northern mid-latitude megacities: Observations versus emission inventories in Los Angeles and Paris, J. Geophys. Res.-Atmos., 118, 2041-2057, doi:10.1002/jgrd.50059, 2013.

Cai, C. J., Geng, F. H., Tie, X. X., Yu, Q., An, J. L.: Characteristics and source apportionment of VOCs measured in Shanghai, China, Atmos. Environ., 44, 5005-5014, 2010.

Cao, J.-J., Zhu, C.-S., Tie, X.-X., Geng, F.-H., Xu, H.-M., Ho, S. S. H., Wang, G.-H., Han, Y.-M., and Ho, K.-F.: Characteristics and sources of carbonaceous aerosols from Shanghai, China, Atmos. Chem. Phys., 13, 803-817, doi:10.5194/acp-13-803-2013, 2013.

Chen, C. H., Huang, C., Jing, Q. G., Wang, H. K., Pan, H. S., Li, L., Zhao, J., Dai, Y., Huang, H. Y., Schipper, L., and Streets, D. G.: On-road emission characteristics of heavy-duty diesel vehicles in Shanghai, Atmos. Environ., 41, 5334-5344, 2007.

Chirico, R., DeCarlo, P. F., Heringa, M. F., Tritscher, T., Richter, R., Prévôt, A. S. H., Dommen, J., Weingartner, E., Wehrle, G., Gysel, M., Laborde, M., and Baltensperger, U.: Impact of aftertreatment devices on primary emissions and secondary organic aerosol formation potential from in-use diesel vehicles: results from smog chamber experiments, Atmos. Chem. Phys., 10, 11545-11563, doi:10.5194/acp-10-11545-2010, 2010.

DeCarlo, P. F., Dunlea, E. J., Kimmel, J. R., Aiken, A. C., Sueper, D., Crounse, J., Wennberg, P. O., Emmons, L., Shinozuka, Y., Clarke, A., Zhou, J., Tomlinson, J., Collins, D. R., Knapp, D., Weinheimer, A. J., Montzka, D. D., Campos, T., and Jimenez, J. L.: Fast airborne aerosol size and chemistry measurements above Mexico City and Central Mexico during the MILAGRO campaign, Atmos. Chem. Phys., 8, 4027-4048, doi:10.5194/acp-84027-2008, 2008.

de Gouw, J. A. and Jimenez, J. L.: Organic Aerosols in the Earth's Atmosphere, Environ. Sci. Technol., 43, 7614-7618, 2009.

de Gouw, J. A., Middlebrook, A. M., Warneke, C., Goldan, P. D., Kuster, W. C., Roberts, J. M., Fehsenfeld, F. C., Worsnop, D. R., Canagaratna, M. R., Pszenny, A. A. P., Keene, W. C., Marchewka, M., Bertman, S. B., and Bates, T. S.: Budget of organic carbon in a polluted atmosphere: Results from the New England Air Quality Study in 2002, J. Geophys. Res.-Atmos., 110, D16305, doi:10.1029/2004jd005623, 2005. 
de Gouw, J. A., Brock, C. A., Atlas, E. L., Bates, T. S., Fehsenfeld, F. C., Goldan, P. D., Holloway, J. S., Kuster, W. C., Lerner, B. M., Matthew, B. M., Middlebrook, A. M., Onasch, T. B., Peltier, R. E., Quinn, P. K., Senff, C. J., Stohl, A., Sullivan, A. P., Trainer, M., Warneke, C., Weber, R. J., and Williams, E. J.: Sources of particulate matter in the northeastern United States in summer: 1. Direct emissions and secondary formation of organic matter in urban plumes, J. Geophys. Res.-Atmos., 113, D08301, doi:10.1029/2007JD009243, 2008.

Feng, J. L., Chan, C. K., Fang, M., Hu, M., He, L. Y., and Tang, X. Y.: Characteristics of organic matter in $\mathrm{PM}_{2.5}$ in Shanghai, Chemosphere, 64, 1393-1400, 2005.

Feng, J. L., Li, M., Zhang, P., Gong, S. Y., Zhong, M., Wu, M. H., Zheng, M., Chen, C. H., Wang, H. L., and Lou, S. R.: Investigation of the sources and seasonal variations of secondary organic aerosols in $\mathrm{PM}_{2.5}$ in Shanghai with organic tracers, Atmos. Environ., 79, 614-622, 2013.

Gentner, D. R., Isaacman, G., Worton, D. R., Chan, A. W. H., Dallmann, T. R., Davis, L., Liu, S., Day, D. A., Russell, L. M., Wilson, K. R., Weber, R., Uha, A., Harley, R. A., and Goldstein, A. H.: Elucidating secondary organic aerosol from diesel and gasoline vehicles through detailed characterization of organic carbon emissions, P. Natl. Acad. Sci. USA, 109, 18318-18323, 2012.

Gentner, D. R., Worton, D. R., Isaacman, G., Davis, L. C., Dallmann, T. R., Wood, E. C., Herndon, S. C., Goldstein, A. H., and Harley, R. A.: Chemical composition of gas-phase organic carbon emissions from motor vehicles and implications for ozone production, Environ. Sci. Technol., 47, 11837-11848, 2013.

Gordon, T. D., Tkacik, D. S., Presto, A. A., Zhang, M., Jathar, S. H., Nguyen, N. T., Massetti, J., Truong, T., Cicero-Fernandez, P., Maddox, C., Rieger, P., Chattopadhyay, S., Maldonado, H., Maricq, M. M., and Robinson, A. L.: Primary gas- and particlephase emissions and secondary organic aerosol production from gasoline and diesel off-road engines, Environ. Sci. Technol., 47, 14137-14146, 2013.

Gordon, T. D., Presto, A. A., May, A. A., Nguyen, N. T., Lipsky, E. M., Donahue, N. M., Gutierrez, A., Zhang, M., Maddox, C., Rieger, P., Chattopadhyay, S., Maldonado, H., Maricq, M. M., and Robinson, A. L.: Secondary organic aerosol formation exceeds primary particulate matter emissions for lightduty gasoline vehicles, Atmos. Chem. Phys., 14, 4661-4678, doi:10.5194/acp-14-4661-2014, 2014a.

Gordon, T. D., Presto, A. A., Nguyen, N. T., Robertson, W. H., Na, K., Sahay, K. N., Zhang, M., Maddox, C., Rieger, P., Chattopadhyay, S., Maldonado, H., Maricq, M. M., and Robinson, A. L.: Secondary organic aerosol production from diesel vehicle exhaust: impact of aftertreatment, fuel chemistry and driving cycle, Atmos. Chem. Phys., 14, 4643-4659, doi:10.5194/acp-14-46432014, 2014b.

Grieshop, A. P., Donahue, N. M., and Robinson, A. L.: Laboratory investigation of photochemical oxidation of organic aerosol from wood fires 2: analysis of aerosol mass spectrometer data, Atmos. Chem. Phys., 9, 2227-2240, doi:10.5194/acp-9-2227-2009, 2009.

Guo, H., Zou, S. C., Tsai, W. Y., Chan, L. Y., and Blake, D. R.: Emission characteristics of nonmethane hydrocarbons from private cars and taxis at different driving speeds in Hong Kong, Atmos. Environ., 45, 2711-2721, 2011.
Hallquist, M., Wenger, J. C., Baltensperger, U., Rudich, Y., Simpson, D., Claeys, M., Dommen, J., Donahue, N. M., George, C., Goldstein, A. H., Hamilton, J. F., Herrmann, H., Hoffmann, T., Iinuma, Y., Jang, M., Jenkin, M. E., Jimenez, J. L., Kiendler-Scharr, A., Maenhaut, W., McFiggans, G., Mentel, Th. F., Monod, A., Prévôt, A. S. H., Seinfeld, J. H., Surratt, J. D., Szmigielski, R., and Wildt, J.: The formation, properties and impact of secondary organic aerosol: current and emerging issues, Atmos. Chem. Phys., 9, 5155-5236, doi:10.5194/acp-9-51552009, 2009.

Harley, R. A., Coulter-Burke, S. C., and Yeung, T. S.: Relating liquid fuel and headspace vapor composition for California reformulated gasoline samples containing ethanol, Environ. Sci. Technol., 34, 4088-4094, 2000.

Hayes, P. L., Ortega, A. M., Cubison, M. J., Froyd, K. D., Zhao, Y., Cliff, S. S., Hu, W. W., Toohey, D. W., Flynn, J. H., Lefer, B. L., Grossberg, N., Alvarez, S., Rappengluck, B., Taylor, J. W., Allan, J. D., Holloway, J. S., Gilman, J. B., Kuster, W. C., de Gouw, J. A., Massoli, P., Zhang, X., Liu, J., Weber, R. J., Corrigan, A. L., Russell, L. M., Isaacman, G., Worton, D. R., Kreisberg, N. M., Goldstein, A. H., Thalman, R., Waxman, E. M., Volkamer, R., Lin, Y. H., Surratt, J. D., Kleindienst, T. E., Offenberg, J. H., Dusanter, S., Griffith, S., Stevens, P. S., Brioude, J., Angevine, W. M., and Jimenez, J. L.: Organic aerosol composition and sources in Pasadena, California during the 2010 CalNex Campaign, J. Geophys. Res.-Atmos., 118, 9233-9257, doi:10.1002/jgrd.50530, 2013.

Hou, B., Zhuang, G. S., Zhang, R., Liu, T. N., Guo, Z. G., and Chen, Y.: The implication of carbonaceous aerosol to the formation of haze: Revealed from the characteristics and sources of OC / EC over a mega-city in China, J. Hazard. Mater., 190, 529-536, 2011.

Huang, C., Chen, C. H., Li, L., Cheng, Z., Wang, H. L., Huang, H. Y., Streets, D. G., Wang, Y. J., Zhang, G. F., and Chen, Y. R.: Emission inventory of anthropogenic air pollutants and VOC species in the Yangtze River Delta region, China, Atmos. Chem. Phys., 11, 4105-4120, doi:10.5194/acp-11-4105-2011, 2011.

Huang, C., Lou, D. M., Hu, Z. Y., Feng, Q., Chen, Y. R., Chen, C. H., Tan, P. Q., and Yao, D.: A PEMS study of the emissions of gaseous pollutants and ultrafine particles from gasoline- and diesel-fueled vehicles, Atmos. Environ., 77, 703-710, 2013.

Huang, R. J., Zhang, Y. L., Bozzetti, C., Ho, K. F., Cao, J. J., Han, Y. M., Daellenbach, K. R., Slowik, J. G., Platt, S. M., Canonaco, F., Zotter, P., Wolf, R., Pieber, S. M., Bruns, E. A., Crippa, M., Ciarelli, G., Piazzalunga, A., Schwikowski, M., Abbaszade, G., Schnelle-Kreis, J., Zimmermann, R., An, Z., Szidat, S., Baltensperger, U., El Haddad, I., and Prévôt, A. S. H.: High secondary aerosol contribution to particulate pollution during haze events in China, Nature, 514, 218-222, doi:10.1038/nature13774, 2014.

Huang, X.-F., He, L.-Y., Xue, L., Sun, T.-L., Zeng, L.-W., Gong, Z.-H., Hu, M., and Zhu, T.: Highly time-resolved chemical characterization of atmospheric fine particles during 2010 Shanghai World Expo, Atmos. Chem. Phys., 12, 4897-4907, doi:10.5194/acp-12-4897-2012, 2012.

Huang, X. F., Xue, L., Tian, X. D., Shao, W. W., Sun, T. L., Gong, Z. H., Ju, W. W., Jiang, B., Hu, M., and He, L. Y.: Highly timeresolved carbonaceous aerosol characterization in Yangtze River 
Delta of China: Composition, mixing state and secondary formation, Atmos. Environ., 64, 200-207, 2013.

Hung, H. F. and Wang, C. S.: Formation of secondary organic aerosols and reactive oxygen species from diluted motorcycle exhaust, J. Chin. Inst. Chem. Eng., 37, 491-499, 2006.

Huo, H., Yao, Z. L., Zhang, Y. Z., Shen, X. B., Zhang, Q., Ding, Y., and He, K. B.: On-board measurements of emissions from light-duty gasoline vehicles in three mega-cities of China, Atmos. Environ., 49, 371-377, 2012a.

Huo, H., Yao, Z. L., Zhang, Y. Z., Shen, X. B., Zhang, Q., and He, K. B.: On-board measurements of emissions from diesel trucks in five cities in China, Atmos. Environ., 54, 159-167, 2012 b.

Jathar, S. H., Miracolo, M. A., Tkacik, D. S., Donahue, N. M., Adams, P. J., and Robinson, A. L.: Secondary organic aerosol formation from photo-oxidation of unburned fuel: Experimental results and implications for aerosol formation from combustion emissions, Environ. Sci. Technol., 47, 12886-12893, 2013.

Jimenez, J. L.: Ph. D thesis of Understanding and quantifying motor vehicle emissions with vehicle specific power and TILDAS remote sensing, Massachusetts: Massachusetts Institute of Technology, 53-56, 1999.

Jimenez, J. L., Canagaratna, M. R., Donahue, N. M., Prévôt, A. S. H., Zhang, Q., Kroll, J. H., DeCarlo, P. F., Allan, J. D., Coe, H., Ng, N. L., Aiken, A. C., Docherty, K. S., Ulbrich, I. M., Grieshop, A. P., Robinson, A. L., Duplissy, J., Smith, J. D., Wilson, K. R., Lanz, V. A., Hueglin, C., Sun, Y. L., Tian, J., Laaksonen, A., Raatikainen, T., Rautiainen, J., Vaattovaara, P., Ehn, M., Kulmala, M., Tomlinson, J. M., Collins, D. R., Cubison, M. J., Dunlea, E. J., Huffman, J. A., Onasch, T. B., Alfarra, M. R., Williams, P. I., Bower, K., Kondo, Y., Schneider, J., Drewnick, F., Borrmann, S., Weimer, S., Demerjian, K., Salcedo, D., Cottrell, L., Griffin, R., Takami, A., Miyoshi, T., Hatakeyama, S., S himono, A., Sun, J. Y., Zhang, Y. M., Dzepina, K., Kimmel, J. R., Sueper, D., Jayne, J. T., Herndon, S. C., Trimborn, A. M., Williams, L. R., Wood, E. C., Middlebrook, A. M., Kolb, C. E., Baltensperger, U., and Worsnop, D. R.: Evolution of organic aerosols in the atmosphere, Science, 326, 1525-1529, 2009.

Kleindienst, T. E., Corse, E. W., Li, W., McIver, C. D., Conver, T. S., Edney, E. O., Driscoll, D. J., Speer, R. E., Weathers, W. S., and Tejada, S. B.: Secondary organic aerosol formation from the irradiation of simulated automobile exhaust, J. Air. Waste Manage., 52, 259-272, 2002.

Liu, S., Ahlm, L., Day, D. A., Russell, L. M., Zhao, Y. L., Gentner, D. R., Weber, R. J., Goldstein, A. H., Jaoui, M., Offenberg, J. H., Kleindienst, T. E., Rubitschun, C., Surratt, J. D., Sheesley, R. J., and Scheller, S.: Secondary organic aerosol formation from fossil fuel sources contribute majority of summertime organic mass at Bakersfield, J. Geophys. Res.-Atmos., 117, D00V26, doi:10.1029/2012JD018170, 2012.

Liu, Y., Shao, M., Fu, L. L., Lu, S.H., Zeng, L. M., and Tang, D. G.: Source profiles of volatile organic compounds (VOCs) measured in China: Part I, Atmos. Environ., 42, 6247-6260, 2008.

May, A. A., Nguyen, N. T., Presto, A. A., Gordon, T. D., Lipsky, E. M., Karve, M., Gutierrez, A., Robertson, W. H., Zhang, M., Brandow, C., Chang, O., Chen, S., Cicero-Fernandez, P., Dinkins, L., Fuentes, M., Huang, S. M., Ling, R., Long, J., Maddox, C., Massetti, J., McCauley, E., Miguel, A., Na, K., Ong, R., Pang, Y., Rieger, P., Sax, T., Truong, T., Vo, T., Chattopadhyay, S., Maldonado, H., Maricq, M. M., and Robinson, A. L.: Gas- and particle-phase primary emissions from in-use, on-road gasoline and diesel vehicles, Atmos. Environ., 88, 247-260, 2014.

Na, K., Kim, Y. P., Moon, I., and Moon, K. C.: Chemical composition of major VOC emission sources in the Seoul atmosphere, Chemosphere, 55, 585-594, 2004.

Nordin, E. Z., Eriksson, A. C., Roldin, P., Nilsson, P. T., Carlsson, J. E., Kajos, M. K., Hellén, H., Wittbom, C., Rissler, J., Löndahl, J., Swietlicki, E., Svenningsson, B., Bohgard, M., Kulmala, M., Hallquist, M., and Pagels, J. H.: Secondary organic aerosol formation from idling gasoline passenger vehicle emissions investigated in a smog chamber, Atmos. Chem. Phys., 13, 6101-6116, doi:10.5194/acp-13-6101-2013, 2013.

Odum, J. R., Jungkamp, T. P. W., Griffin, R. J., Forstner, H. J. L., Flagan, R. C., and Seinfeld, J. H.: Aromatics, reformulated gasoline, and atmospheric organic aerosol formation, Environ. Sci. Technol., 31, 1890-1897, 1997.

Platt, S. M., El Haddad, I., Zardini, A. A., Clairotte, M., Astorga, C., Wolf, R., Slowik, J. G., Temime-Roussel, B., Marchand, N., Ježek, I., Drinovec, L., Mocnik, G., Möhler, O., Richter, R., Barmet, P., Bianchi, F., Baltensperger, U., and Prévôt, A. S. H.: Secondary organic aerosol formation from gasoline vehicle emissions in a new mobile environmental reaction chamber, Atmos. Chem. Phys., 13, 9141-9158, doi:10.5194/acp-13-91412013, 2013.

Robinson, A. L., Donahue, N. M., Shrivastava, M. K., Weitkamp, E. A., Sage, A. M., Grieshop, A. P., Lane, T. E., Pierce, J. R., and Pandis, S. N.: Rethinking organic aerosols: Semivolatile emissions and photochemical aging, Science, 315, 1259-1262, 2007.

SCCTPI (Shanghai City Comprehensive Transportation Planning Institute): Shanghai comprehensive transportation annual report, Shanghai, 11 pp., 2012.

Schauer, J. J., Kleeman, M., Cass, G., and Simoneit, B. T.: Measurement of emissions from air pollution sources, 2. C1 through C30 organic compounds from medium duty diesel trucks, Environ. Sci. Technol., 33, 1578-1587, 1999.

Schauer, J. J., Kleeman, M., Cass, G., and Simoneit, B. T.: Measurement of emissions from air pollution sources, 5. C1-C32 organic compounds from gasoline-powered motor vehicles, Environ. Sci. Technol., 36, 1169-1180, 2002.

Stone, E. A., Zhou, J., Snyder, D. C., Rutter, A. P., Mieritz, M., and Schauer, J. J.: A comparison of summertime secondary organic aerosol source contributions at contrasting urban locations, Environ. Sci. Technol., 43, 3448-3454, 2009.

Takegawa, N., Miyakawa, T., Kondo, Y., Jimenez, J. L., Zhang, Q., Worsnop, D. R., and Fukuda, M.: Seasonal and diurnal variations of submicron organic aerosol in Tokyo observed using the Aerodyne aerosol mass spectrometer, J. Geophys. Res.-Atmos., 111, D11206, doi:10.1029/2005JD006515, 2006.

Turpin, B. J. and Lim, H. J.: Species contributions to $\mathrm{PM}_{2.5}$ mass concentrations: Revisiting common assumptions for estimating organic mass, Aerosol Sci. Technol., 35, 602-610, 2001.

Wang, H. K., Chen, C. H., Huang, C., and Fu, L.X.: On-road vehicle emission inventory and its uncertainty analysis for Shanghai, China, Sci. Total Environ., 398, 60-67, 2008.

Wang, H. L., Chen, C. H., Wang, Q., Huang, C., Su, L. Y., Huang, H. Y., Lou, S. R., Zhou, M., Li, L., Qiao, L. P., and Wang, Y. H.: Chemical loss of volatile organic compounds and its impact on the source analysis through a two-year continuous measurement, Atmos. Environ., 80, 488-498, 2013. 
Wang, J., Jin, L. M., Gao, J. H., Shi, J. W., Zhao, Y. L., Liu, S. X., Jin, T. S., Bai, Z. P., and Wu, C. Y.: Investigation of speciated VOC in gasoline vehicular exhaust under ECE and EUDC test cycles, Sci. Total Environ., 445-446, 110-116, 2013.

Weitkamp, E. A., Sage, A. M., Pierce, J. R., Donahue, N. M., and Robinson, A. L.: Organic aerosol formation from photochemical oxidation of diesel exhaust in a smog chamber, Environ. Sci. Technol., 41, 6969-6975, 2007.

Wu, Y., Zhang, S. J., Li, M. L., Ge, Y. S., Shu, J. W., Zhou, Y., Xu, Y. Y., Hu, J. N., Liu, H., Fu, L. X., He, K. B., and Hao, J. M.: The challenge to $\mathrm{NO}_{\mathrm{x}}$ emission control for heavy-duty diesel vehicles in China, Atmos. Chem. Phys., 12, 9365-9379, doi:10.5194/acp12-9365-2012, 2012.

Ye, B. M., Ji, X. L., Yang, H. Z., Yao, X. H., Chan, C. K., Cadle, S. H., Chan, T., Mulawa, P. A.: Concentration and chemical composition of $\mathrm{PM}_{2.5}$ in Shanghai for a 1-year period, Atmos. Environ., 37, 499-510, 2003.
Yuan, B., Hu, W. W., Shao, M., Wang, M., Chen, W. T., Lu, S. H., Zeng, L. M., and Hu, M.: VOC emissions, evolutions and contributions to SOA formation at a receptor site in eastern China, Atmos. Chem. Phys., 13, 8815-8832, doi:10.5194/acp-13-88152013, 2013.

Zhang, Y. L., Wang, X. M., Zhang, Z., Lü, S. J., Shao, M., Lee, S. C., and Yu, J. Z.: Species profiles and normalized reactivity of volatile organic compounds from gasoline evaporation in China, Atmos. Environ., 79, 110-118, 2013.

Zhao, Y. L., Hennigan, C. J., May, A. A., Tkacik, D. S., de Gouw, J. A., Gilman, J. B., Kuster, W. C., Borbon, A., and Robinson, A. L.: Intermediate-volatility organic compounds: a large source of secondary organic aerosol, Environ. Sci. Technol., 48, 1374313750, 2014. 